\title{
Kent Parklarındaki Kullanım Alanlarının Estetik ve Fonksiyonel Özelliklerinin Kullanıcı Görüşleri Doğrultusunda İrdelenmesi "Antalya Muratpaşa Prof. Dr. Erdal İnönü Kent Parkı Örneği \\ Investigation of The Aesthetics and Functional Properties of The Areas in Urban Parks in accordance with The User Opinions in Example of Antalya Muratpaşa Prof. Dr. Erdal İnönü The City Park
}

\section{Orhun SOYDAN ${ }^{1 *}$, Ahmet BENLIAY ${ }^{2 *}$, Amılcan AKBULUT ${ }^{3}$}

${ }^{1}$ Niğde Ömer Halisdemir Üniversitesi, Mimarlık Fakültesi, Peyzaj Mimarlığı Bölümü

${ }^{2-3}$ Akdeniz Üniversitesi, Mimarlık Fakültesi, Peyzaj Mimarlığı Bölümü

Article history: Received 19-04-2019 / Accepted 11-07-2019

\section{ÖZET}

Amaç: Bu çalışmada Antalya ili Muratpaşa ilçesinde bulunan Prof. Dr. Erdal İnönü Kent Parkı içerisinde bulunan kullanım alanları, kullanıcı görüşleri açısından estetik ve fonksiyonel kriterlere göre değerlendirilmiştir. Yöntem: Çalışmada, park içerisinde bulunan kullanım alanları belirlenmiş ve her bir kullanım alanının haritası oluşturulmuştur. Kullanıcıların park hakkındak düşüncelerinin alınması amacıyla anket çalışması yürütülmüştür. Elde edilen veriler bilgisayar ortamında tanımlayıcı istatistikler kullanılarak değerlendirilmiştir. Anket çalışmasından elde edilen veriler sonucunda parkın her bir kritere göre haritası oluşturulmuştur. Bulgular: Parkın batısında yer alan meydan ve park girişinin en yüksek tercih düzeyine sahip olduğu belirlenmiştir. Çalışma alanın ortasında bulunan kır kahvesi, kafe ve yüzme havuzu çevresinin tercih düzeylerinin daha az olduğu tespit edilmiştir. Çalışma alanının doğu ve güneydoğusunda yer alan dernek binası ve çocuk oyun alanı kullanıcılar tarafından tercih edilmemektedir. Yaş, meslek, gelir gibi değişkenlere bağlı olarak kullanıcı tercihleri anlamlı farklılıklar göstermektedir. Eğitim ve cinsiyet değişkenlerinde anlamlı bir farklılık göstermemektedir. Sonuç: Yapılmış olan peyzaj tasarımının başarıya ulașmasının temel amacı insanlar tarafından tercih edilmesidir. Bu yüzden herhangi bir alanda peyzaj tasarımı yapılmadan önce, kullanıcılar araştırılmalı, istek ve talepleri alınmalı, peyzaj tasarımı bu yönde geliştirilmelidir.

Anahtar Kelimeler: Kent Parkı, Park, Estetik, İşlevsellik

\section{ABSTRACT}

Aim: In this study, areas in the Prof. Dr. Erdal Inönu City Park were evaluated in terms of user opinions according to aesthetic and functional criteria. Method: The areas in the park have been determined and maps were created for each area. A survey study was conducted in order to get the opinions of the users about the park. Data was evaluated by using descriptive statistics. As a result of the data obtained from the survey study, the map was created according to each criteria. Results: There is determined that square and entrance of the park are the most favorite areas in the park. Garden, cafe and surround of ornamental pool which are found in the middle of the park, are less favorite areas in the park. Building and playground which are found in the east and southwest of the park, are not favorite by users. Preferences have shown significant difference according to variables such as age, occupation and income. But preferences have not shown significant difference according to variables such as education and sex. Conclusion: The main purpose of the success of the landscape design is to be liked by users. Therefore, before landscaping design is done in any area, users should be investigated, requests and demands should be taken and landscape design should be developed in this direction.

Keywords:Urban Park, Park, Aesthetic, Functionality

\section{GIRIŞ}

Açık alanların planlanması ve tasarımı; felsefe, sanat, din, kişisel ve toplumsal tercihler, ekonomi, ekoloji vb. pek çok girdiyi içeren disiplinler arası bir çalışmadır (Graham, 1995: 2324). Bu bağlamda kentliye temel olarak "doğayı" ve "rekreasyonu" sunan parklar; tarih boyunca değişen dinamiklerin etkisiyle oluşturulmuş ve kullanılmışlardır (Kurtaslan, 2017: 744-745). Doğal güzellikleri ve özellikleri yönünden kentlerin en seçkin yerlerinde her yaş grubunun rahatlıkla kullanabileceği özelliklere sahip olacak şekilde planlanan kent parkları, koruma ve kullanma dengesi içerisinde eğitime olanak sağlar. Aynı zamanda kent parkları toplumsal yaşamı da düzenler (Özkır, 2007: 11-12).

Kent parkları, kentlerin doğal ve kültürel özellikleri yönünden en prestijli alanlarında bulunması gereken, genellikle odak noktalarına konumlandırılan, kentin ekolojik dengesini korumak ve kentlinin rekreasyon ihtiyacını karşılamak üzere, içinde toplumu oluşturan her yaş grubundan insanın aktif-pasif rekreasyon gereksinmelerini karşılamaya yönelik tesis ve olanaklara yer veren fonksiyonel ve estetik kent içi açık ve yeşil alanlardır. Şehirlerin estetik

*Corresponding author. Tel.:

E-mail address: orhunsoydan@akdeniz.edu.tr http://dx.doi.org/10.16950/iujad.556154 ORCID: 
ve mimari formlarının güçlü bir elemanı olmalarının yanı sıra, sosyal kaynaşmayı sağlama, toplumsal gelişmeyi körükleme, ekonomik amaç ve aktiviteleri destekleme, eğitim gibi kent ve kent insanı için önemli olan pek çok fonksiyonu barındırır. Kentteki varlıkları değerli hale getiren ve sürdürülebilir şehirler için önemli rol oynayan kent parkları, kentsel çevreye fiziksel ve estetik kalite açısından önemli katkılar sağlayan, kent ortamının getirdiği baskıları hafifletebilecek rekreasyonel imkânlar sunan ve kentli halkın birçok sosyal ve psikolojik gereksinimlerini karşılamalarına katkıda bulunan alanlardır (Şatıroğlu ve diğ., 2017: 539540).

Parkların sahip olduğu değerleri bulundukları ortamlara yansıtmaları için iyi bir planlama ve tasarım süreci gerekmektedir. Parkı kullanacak olan yakın çevredeki insanların ihtiyaçlarına (eğlence, dinlenme, huzur, spor vb.) cevap verecek şekilde planlama ve tasarımının yapılması gerekmektedir. Ayrıca yapılacak olan parkı, diğer parklardan ayıracak bir tasarımının olması uluslararası tanınırlığı açısından da oldukça önemlidir. Park için hazırlanan peyzaj tasarımının uygulanmasının ardından bakım ve temizlik işlemlerinin de zamanında yapılması oldukça önemlidir. Dünyada bu açıdan örnek olabilecek parkları incelediğimizde Amerika Birleşik Devletleri'nde bulunan "Central Park" ve İngiltere de bulunan "Hyde Park" çalışma kapsamında incelenmiştir.

Öncelikle Central Park'ın genel özellikleri incelenmiştir. Central Park, Amerika Birleşik Devletleri'nde tasarımı yapılan ilk genel parktır. 341 hektar genişliğinde bir alana sahiptir. New York kentinin uluslararası bir şöhret sağlaması için zengin tüccarlar ve alan sahipleri parkın yapımını desteklemişlerdir. Park, 1877 yılında kullanıma açılmıştır (Özkır, 2007: 5354). Central Parkın dış mekân tasarımında estetik bütünlüğün yanı sıra, fonksiyonun dea çok önemli olduğu vurgulanmıştır. İyi tasarlanmış kentsel peyzaj alanlarının kente ilişkin fonksiyonlarıyla birlikte, kentin fiziksel ve ekonomik gelişmesinde yön verici olduğu da gösterilmiştir (Özkır, 2007: 56-57). Central Park, barındırdığı büyük bir vadi, kuzey ve güney çayırları, çilek tarlaları, büyük çimen alanları ve yaya sirkülâsyon ağı ile ziyaretçileri su kıyılarından, arzın yüksek kayalıklarına kadar büyük bir ölçek görsel deneyim fırsatı sunmaktadır (Nasuh, 1993: 13-14).

Central Park'ın ardından Hyde Park'ın genel özellikleri incelenmiştir. Planlama ve tasarım süreci açısından kullanıcıların beklenti düzeyine karşılayan bir diğer park ise "Hyde park "tır. Adını Hyde malikânesinden alan park, 140 hektar büyüklüğündedir. Park'ın özel bir tarihî veya estetik karakterinin olmamasının yanı sıra diğer parklardan farklı bir etkiye sahiptir. Hyde Park uzun yıllar boyunca çok büyük baskı altında olmasına rağmen zamana karşı direnmiştir. Londralılara günlük yaşamın baskısından kaçışlar için olanak sağlamış olan park, İngiliz kırsal çevresinin ulu ağaçlarını, geniş çim alanlarını ve su yüzeylerini, kullanıcıların yakınına getirerek onların ruh ve beden sağlığını korumayı amaçlamaktadır (Ocak ve diğ., 2014: 15-16). Hyde Park'ta benimsenen Londra Parkı düşüncesiyle, kalabalık caddelerden kurtulma duygusunu verecek hayallerdeki mekânın oluşturulması istenmiştir (Oğuz, 1998: 13-14). Hyde Park, Londralılara gün boyu oturma, kitap okuma, sohbet etme, yaklaşık 3 hektarlık olan gezinti yolunda yürüyüş, çim alanlar üzerinde geniş oyun alanları vb. olanaklar sunmaktadır. Parkın en orijinal köşelerinden biri kuzeydoğu köşesindeki serbest konuşma kürsüsüdür. Bu alan çok sayıda ziyaretçiyi parka çekmektedir. Hyde Park yalnızca İngiltere'nin değil belki de dünyanın en yoğun alışveriş merkezlerinden birine yakın olmasına karşın bütün kullanıcılarına sükûnet ve rekreasyon olanağı verebilmektedir (Oğuz, 1998: 1819).

Bu parkların planlama ve tasarım süreçlerinin entegrasyonun sağlanması, kullanıcı profili düşünülerek özgün değerlere sahip olması, bakım ve temizlik işlemlerinin zamanında yapılması sayesinde çok fazla sayıda ziyaretçiyi kendilerine çektikleri rahatlıkla söylenebilir.

Parklar, özellikleri, fonksiyonları ve sağladığı olanaklar kapsamında kentlerdeki insanların yaşamında oldukça önemlidir. Kent parklarının özellikleri değerlendirildiğinde kullanıcılara sağladığı faydalar yalnızca fiziksel olmayıp, duygusal ve bilişsel olarak da faydaları olabileceği düşünülmektedir. Bu kapsamda, parklarda yapılan fiziksel aktivitelerin yanı sıra, güzel bir park ortamında bulunmanın mutluluk getirebileceği, aynı zamanda da parktaki peyzaj çalışmalarının o parkı kullananların düşünce dünyasında önemli bir yeri olduğu söylenebilir (Sonkur ve diğ., 2017: 1-2).

Kullanıcıların kent parklarından memnuniyeti, kullanıcı tipine bağlı olarak değişiklik gösterir. Kullanıcı memnuniyetinin en yüksek düzeyde olması için çeşitli yaş grupları, cinsiyet, eğitim ve meslek gruplarının istek ve ihtiyaçlarına hizmet vermesi önemlidir. Bununla birlikte kent parklarının kullanıcılar tarafından benimsenmesi için kolay ulaşılabilirliğinin olması, sosyal ve kültürel etkileşime olanak sağlaması, içerisinde çeşitli rekreasyonel aktiviteleri barındıracak 
şekilde tasarlanması önemlidir. Ayrıca park güvenliğinin, temizliğinin ve bakımının sağlanması da bir diğer önemli husustur (Özkır, 2007: 13-14).

Kent parkları, bulundukları alanlara ekonomik, ekolojik, estetik ve fonksiyonel olarak katkıda bulunurlar. Parkların kentlere sunmuş olduğu ekolojik katkılar, sadece o alanla sınırlı kalmayıp yakın çevresini de etkilemektedir. İklim, yaban hayatı, toprak özellikleri, yağmur sularının yönetimi vb. konular açısından kent yaşamı etkilenmektedirler. Bu katkıların tespit edilmesi, kullanıcı görüşlerinin yanında çeşitli nicel verilerin (ölçme, değerlendirme vb.) de kullanılması ile mümkün olmaktadır. Bu yüzden parkların ekolojik kriterlerinin değerlendirilmesi çalışma kapsamı dışında tutulmuştur. Çalışmada parkların sadece estetik ve fonksiyonel kriterleri incelenmiştir.

Bu bağlamda çalışmada, estetik ve güzellik kavramları tanımlanarak kent parklarındaki estetik ve fonksiyon arasındaki ilişki ortaya konulmuştur. Bütün bu değerlendirmeler ışığında estetik arayışların olumlu sonuçlara ulaşabilmesi için oluşturulan mekânların, yaşayan, yaşanılan ve insanlara estetik bilinci aşılayan nitelikte olması gerekmektedir. Bu çalışmada kent parklarının sahip olması gereken fonksiyonlara ve estetik kriterlere değinilerek "Prof. Dr. Erdal İnönü Kent Parkı" bu kapsamda incelenmesi amaçlanmıştır. Yurt içi ve yurt dışından birer örnek alınarak tarihsel süreçteki fonksiyon değişikliklerinin incelenip birbirleriyle karşılaştırılmasıyla araştırıcıların ve konuyla ilgilenenlerin bu konuda yapacakları çalışmalara bir alt yapı oluşturabileceği düşünülmüştür.

Bu çalışmanın amacı; Antalya İli Muratpaşa İlçesi Şirinyalı Mahallesinde bulunan ve Haziran 2017 de kullanıma açılan "Prof. Dr. Erdal İnönü Kent Parkı" içerisinde yer alan kullanım alanlarının, kullanıcı görüşleri doğrultusunda, estetik ve fonksiyonel kriterler açısından değerlendirilmesidir.

Çalışılan kent parkının estetik ve fonksiyonel ihtiyaçlara ne düzeyde cevap verdiği bu çalışma kapsamında incelenmiştir. Araştırma sonuçlarının belirlenip bu sonuçların tasarım sürecine dahil edilmesinin Antalya İlinde yapılması planlanan parklara yeni bir vizyon kazandıracağı düşünülmektedir.

Çalışmanın temel sorusu ise şu şekildedir:

1. Parkların peyzaj tasarımı sürecinde estetik ve fonksiyonel kriterler önemsenmekte midir?

2. Peyzaj tasarımı sürecine kullanıcı görüşleri alınarak mı başlanmaktadır? Yapılan parklar kullanıcıların estetik ihtiyaçlarını karşılamakta mıdır?

Bu sorular kapsamında parkların tasarım sürecinin nasıl olduğu, parkların tasarım süreçleri içerisinde estetik ve fonksiyonel kriterlerinin neler olduğunun tespit edilmesi bu çalışmanın amaçları içerisinde yer almaktadır.

\section{MATERYAL ve YÖNTEM}

Çalışma alanı olan "Prof. Dr. Erdal İnönü Kent Parkı" Antalya ili Muratpaşa İlçesi Şirinyalı Mahallesinde yer almaktadır. Kent Parkının kuzeyinde "Eski Lara caddesi" batısında ise "Akra Barut Hotel" bulunmaktadır. Toplam alanı 25 dönüm olan Prof. Dr. Erdal İnönü Kent Parkı içerisinde çeşitli kullanım alanları yer almaktadır. Parkın konumu Şekil 1'de verilmiştir. 


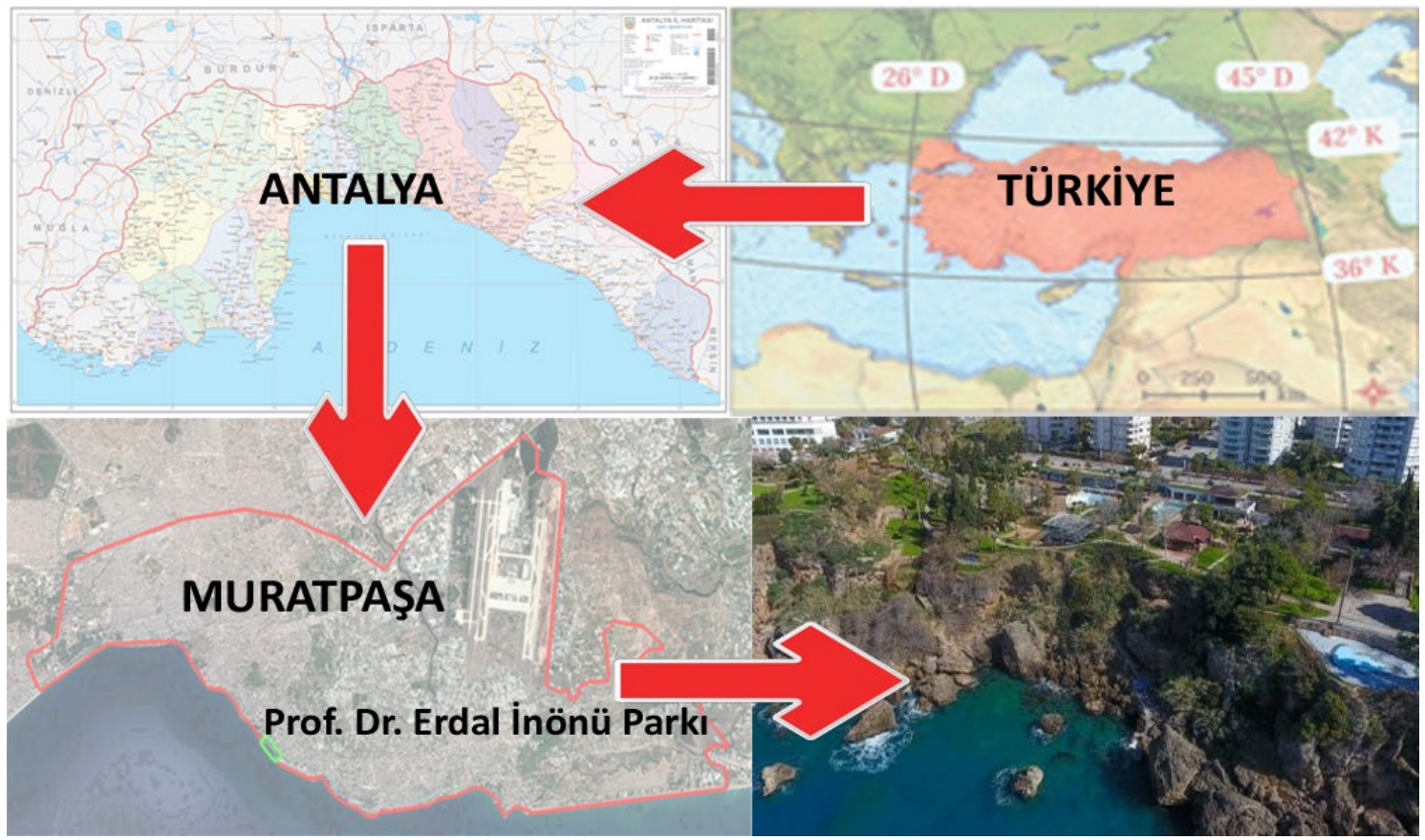

Şekil 1. Parkın konumu

Parkın mevcut alan kullanımlarının tespit edilmesi (çocuk oyun alanı, havuz, meydan vb.), parkta yer alan kullanımların (aquapark, kafe, yapı vb.) belirlenmesi amacıyla parka ait olan "peyzaj uygulama projesi" Antalya Muratpaşa Belediyesi Park ve Bahçeler Müdürlügü̈nden temin edilmiştir. Elde edilen bu harita sayesinde park içerisinde bulunan kullanım alanlarının neler olduğu ve alandaki dağılımları tespit edilmiştir. Ayrıca parka ait tasarım ile uygulama arasında farklıığın olup olmadığı araştırılmış, yapılan arazi gözlemleri sonucunda tasarım ile uygulama arasında herhangi bir farklılığın bulunmadığı tespit edilmiştir. Elde edilen harita üzerinden her bir alan kullanımın dağılımlarının tespit edilmesi amacıyla Arc-MAP 10.1 yazılımı kullanılmıştır. Oluşturulan bu harita çalışmanın temel haritasını oluşturmuştur. Çalışma kapsamında parkın sınırları çizilirken doğal ve yapay sınırlar dikkate alınmıştır. Parkın güneyinde bulunan deniz parkın bu kısmındaki sınııını oluştururken, kuzey, batı ve doğu cephelerinde bulunan ana yol parkın bu yönlerdeki sınırını oluşturmuştur.

Daha sonra park üzerinde çeşitli analizler yapılmış ve parkın fotoğrafları çekilmiştir. Alan üzerinde bulunan her bir kullanımın fotoğrafı çekilmiştir. Bunun yapılma amacı ise; park üzerinde bulunan kullanımların estetik ve fonksiyonel kriterlere göre kullanıcı görüşleri doğrultusunda değerlendirilmesidir. Her bir kullanımın aldıkları ortalama puanlar belirlenmiş̧ir. Yapılan gözlemler sonucunda park içerisinde toplam 11 kullanım alanının olduğu tespit edilmiştir. Bunlar; çocuk oyun alanı, kır kahvesi, yüzme havuzu, aquapark, kafe, restaurant, seyir terası, nikâh salonu, dul ve yetimler dernek binası, plaj ve güneşlenme terası, park meydanı olarak tespit edilmiştir. Çalışma kapsamında nikâh salonu ve dernek binasının olduğu alanla, restaurant'ın olduğu alanlar günün belirli saatlerinde kullanıldığından dolayı çalışma kapsamına alınmamıştır. Geriye kalan 9 kullanım alanı estetik ve fonksiyonel kriterler doğrultusunda değerlendirilmiştir.

Estetik ve fonksiyonel kriterler daha önce yapılmış çalışmalar ve park tasarımı ile ilgili çalışmış olan uzmanların görüşleri sonucunda belirlenmiştir. Çalışma kapsamında öncelikle parkın fonksiyonel (işlev) kriterleri kullanıcı görüşleri doğrultusunda değerlendirilmiştir. Çalışma kapsamında; yönlendirici, dinlendirici, kötü görüntü perdeleme özelliği var, iklim için uygun, yaşılılar için uygun, engelliler için uygun, odak özelliği var olmak üzere toplam 7 adet fonksiyonel kriter tespit edilmiştir. Park içerisinde yer alan 9 kullanım bu kriterler doğrultusunda değerlendirilmiştir. En düşük "1" puan, en yüksek " 5 " puan olacak şekilde her bir kullanımın fonksiyonel kriterler açısından aldıkları ortalama puanlar tespit edilmiştir.

Fonksiyonel kriterlerinin belirlenmesinin ardından her bir kullanımın estetik kriterler açısından almış oldukları puanlar tespit edilmiştir. Çalışma kapsamında; çekici, güzel, bakımlı, çevreyle uyumlu, doğal, görkemli, şaşırtıcl, hareketli, geometrik, ferahlatıcı, büyük olmak üzere toplam 11 adet estetik kriter tespit edilmiştir. Estetik kriterler de fonksiyonel kriterler gibi bir puanlama sistemi ile park içerisindeki kullanımların almış oldukları toplam puanlar tespit edilmiştir. 
Parkın her bir kullanımı için estetik ve fonksiyonel kriterlere göre almış oldukları puanların haritaları oluşturulmuş ve yorumlanmıştır. Bu haritalama işleminde Arc- MAP 10.1 yazılımında bulunan "kriging yöntemi" kullanılmıştır. Bu yöntemle her bir kullanımın almış olduğu değerler haritada işlenmiş ve her bir kullanımın bölgelerine göre almış oldukları ortalama değerler tespit edilmiştir.

Çalışma kapsamında parkın estetik ve fonksiyonel kriterler açısından almış oldukları puanların ve parkın kullanım amaçlarının tespit edilmesi için anket çalışması uygulanmıştır. Anket soruları, daha önce yapılmış çalışmalardan farklı olarak çalışma kapsamında özgün olacak şekilde hazırlanmıştır. Kullanıcılar üzerinden yapılan anket çalışması Microsoft Office - Word yazılımı kullanılarak oluşturulmuştur. Anket sorularını veriler cevaplar ise SPSS 20.0 yazılımına işlenmiş ve yorumlanmıştır. Bu verilerin analiz edilip yorumlanması amacıyla betimleyici ve açıklayıcı istatistiki yöntemlerden faydalanılmıştır. Anket çalışması ve alan analizlerinden elde edilen bulguların yorumlanmasıyla parkın estetik ve fonksiyonel kriterleri değerlendirilmiştir.

Çalışma yöntemi 5 aşamadan oluşmaktadır. Birinci aşamada çalışma konusuyla ilgili literatürde bulunan kitap, tez, makale, bildiri gibi kent ve mahalli parkların estetik ve fonksiyonel kriterleriyle ilgili yapılan çalışmalar incelenmiştir.

İkinci aşama ise; araştırma alanına ait verilerin toplanması ve arazi çalışmalarının yapılmasıdır. Bu aşamada çalışma alanında yapılan arazi gezileri ile kent parkında bulunan kullanım alanlarının fiziksel özellikleri incelenip çeşitli açılardan fotoğraflar çekilmiştir.

Üçüncü aşama; anket formunun hazırlanması, örneklemin belirlenmesi ve kullanıcılara yönelik anket çalışmasının gerçekleştirilmesi aşamasıdır. Bu aşamada; kent parkının genel kullanım özelliklerini ve parkta bulunan kullanım alanlarının kullanıcılar tarafından tercih durumlarının belirlenmesi amacıyla anket formu hazırlanmıştır. Çalışma kapsamında hazırlanan anket formu diğer çalışmalardan farklı olarak özgün hazırlanmıştır. Çalışma da kullanılan anket toplam 2 bölümden oluşmaktadır. Birinci bölümde kullanıcılara ait demografik özellikler ve yaşadıkları bölgeler (sosyo - ekonomik durum) sorulmuştur. Anket çalışmasının ikinci bölümünde ise parkta daha önce belirlenmiş olan 9 kullanım alanının estetik ve fonksiyonel kriterler açısından değerlendirilmesi istenmiştir. Anket çalışmasında toplam 25 soru bulunmaktadır. Anket çalışması 2019 yılı Ocak ve Mayıs ayları arasında park kullanıcılarına uygulanmıştır. Antalya İli açısından yazın dış mekânın çok sıcak olması, ocak ayına kadar yağışın fazla olması nedeniyle insanların dış mekânda fazla vakit geçirmedikleri tespit edilmiştir. Bu sebepten dolayı iklim şartlarının en iyi olduğu Şubat- Mayıs ayları arasında anket çalışması uygulanmıştır.

2018 yılı TÜİK verilerine göre Antalya İlinin nüfusu 2.426.356'dır. Yazıcıoğlu ve Erdoğan’a göre (2004: 5-51) evren büyüklüğü 1.000 .000 ile 100.000 .000 arasında olan örneklem için \%5 hata oranı ve \% 95 güven aralığında 384 anketin yeterli olacağı tespit edilmiştir. Buna göre yapılacak anket çalışmasında hataların da olacağı düşünülerek 400 kullanıcıya anket çalışması yapılmıştır. Hazırlanan anket formu ile pilot çalışmalar gerçekleştirilmiş ve sonrasında bazı sorular, soruların formatları ve puanlama sistemi güncellenerek nihai soru formu hazırlanmıştır. Anket formu;

1. Kent parkında yer alan kullanım alanlarının estetik kriterlere göre değerlendirilmesi

2. Kent parkında yer alan kullanım alanlarının fonksiyonel kriterlere göre değerlendirilmesi

3. Katılımcıların sosyoekonomik özellikleri ile ilgili bölümlerden oluşmaktadır.

Katılımcıların sosyoekonomik özellikleri; bu bölümde ankete katılanların sosyoekonomik özelliklerini belirlemek amacıyla, katılımcılara yaş, cinsiyet, eğitim durumu, çalışma durumu, gelir durumu ile ilgili sorular yöneltilmiştir.

Katılımcıların parka ait düşüncelerinin (estetik ve fonksiyonel kriterler doğrultusunda); Estetik ve fonksiyonel değerlendirme çizelgeleriyle, kent parkındaki kullanım alanlarının kullanıcılarda bıraktığı fiziksel, görsel, işitsel, psikolojik etkiler ve fonksiyonları yerine getirdikleri ve/veya getirmedikleri kullanıcı görüşleri belirlenmeye çalışılmıştır. Kullanıcılara parkın kullanım alanlarına yönelik fikirleri sorulurken 5'li likert ölçeği kullanılmıştır. En düşük "1" puan (hiç beğenmiyorum), "5" en yüksek puan (çok beğeniyorum) olacak şekilde değerlendirmeleri istenmiştir. Daha sonra her bir kullanım alanının almış oldukları ortalama puanlar tespit edilmiş ve yorumlanmıştır. Toplam 11 adet estetik ve 7 adet fonksiyonel kriter tespit edilmiştir.

Dördüncü aşamada; anketten elde edilen veriler SPSS 20.0 yazılımı vasıtasıyla bilgisayar ortamına aktarımıştır. Veri giriş işlemi bittikten sonra frekans (sıklık analizi) tabloları 
hazırlanarak veri kontrolleri gerçekleştirilmiştir. Frekans (sıklık analizi) analizleri sonucu elde edilen veriler her bir frekans (sıklık analizi) değeri farklı rengi temsil edecek şekilde haritalanarak tüm kriterlerin çalışma alanında yer alan 9 kullanım alanına dağılımı gerçekleştirilmiştir. Haritalama işlemleri için Arc-MAP 10.1 yazılımı kullanılmıştır. Bölgelerin almış oldukları ortalama puanların tespiti için Arc-MAP 10.1 yazılımında bulunan "kriging yöntemi" kullanılmıştır. Veriler iki farklı yöntemle analiz edilmiştir. İlk olarak sıklık analizleri yapılarak ankete katılanların sorulara verdikleri yanıtlara ulaşılmıştır. İkinci basamakta ise, katılımcıların nitelik uygunluğu, estetik ve fonksiyonel değerlendirme sorularına yaş, cinsiyet ve eğitim özelliklerine göre anlamlı farklılıklar gösterip göstermediğini belirlemek amacıyla veriler arasında ki-kare bağımsızlık testleri uygulanarak çapraz tablolar hazırlanmıştır.

Son olarak beşinci aşamada ise; elde edilen veriler ışı̆̆ında çalışılan park estetik ve fonksiyonel kriterlere göre değerlendirilmiş ve parkların peyzaj tasarım süreçlerine yönelik öneriler getirilmiştir.

\section{BULGULAR}

\section{Çalışma Alanının Özellikleri}

Çalışma alanı olan "Prof. Dr. Erdal İnönü Kent Parkı" Antalya İli Muratpaşa ilçesi Şirinyalı Mahallesinde yer almaktadır. Kent Parkının kuzeyinde "Eski Lara caddesi" batısında ise "Akra Barut Hotel" konumlanmıştır. Toplam alanı 25 dönüm olan Prof. Dr. Erdal İnönü Kent Parkı içerisinde çeşitli kullanım alanları yer almaktadır. Bu kullanımlar; Çocuk Oyun Alanı, Kır Kahvesi, Yüzme Havuzu, Aqua Park, Kafe, Restoran, Seyir Terası, Nikâh Salonu, Dul ve Yetimler Derneği, Plaj ve Güneşlenme Terası, Park Meydanı'dır. Parka içerisinde bulunan havuz ve aqupark Şekil 2'de verilmiştir. Park içerisinde bulunan süs havuzu ve yürüyüş yolları ise Şekil 3'de verilmiştir.

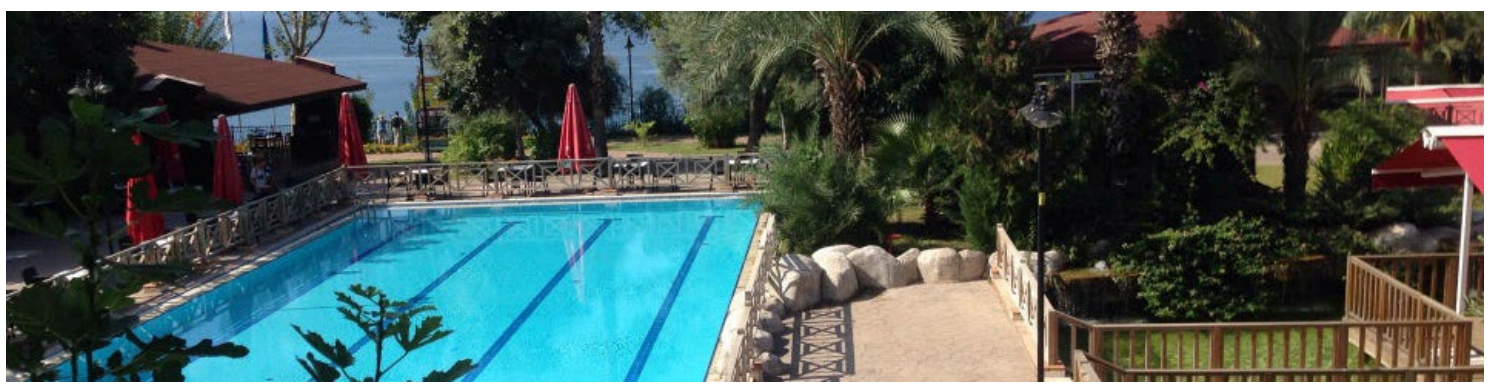

Şekil 2. Park içerisinde bulunan yüzme havuzu

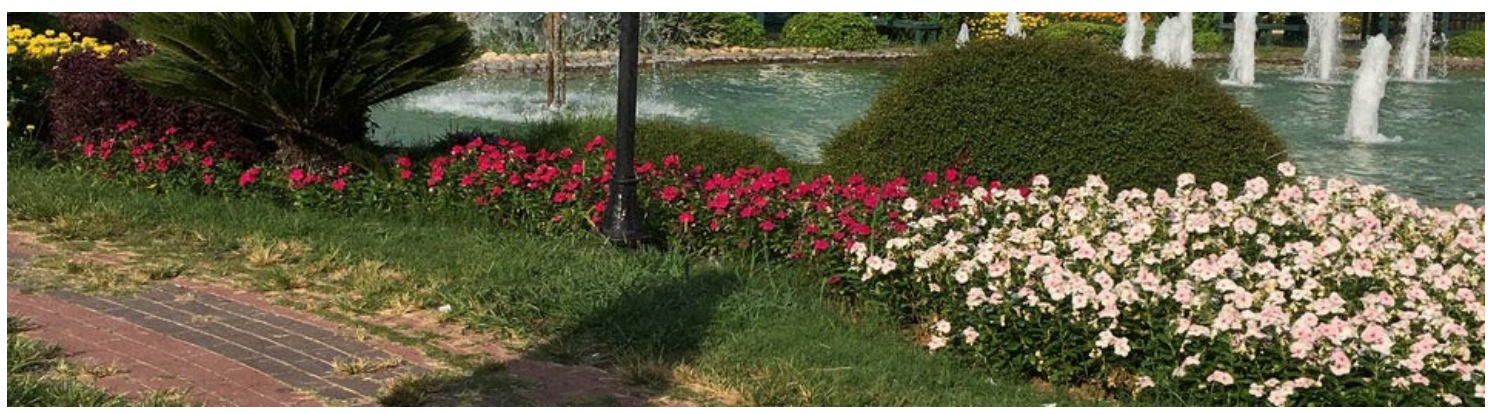

Şekil 3. Park içerisinde bulunan süs havuzu ve yürüyüş yolları

\section{Park Kullanıcılarının Profili ve Parkı Kullanım Şekilleri}

Bu bölümde park kullanıcılarının sosyo-ekonomik durumları ve çalışma alanına gitme amaçları ifade edilmektedir. Anket çalışmasına katılanların cinsiyetlerinin dağılımı Tablo 1'de verilmiştir.

Tablo 1. Katılımcıların cinsiyet dağılımı

\begin{tabular}{lrr}
\hline Cinsiyet & Kişi Sayısı & Yüzde(\%) \\
\hline Kadın & 171 & 42,8 \\
\hline Erkek & 229 & 57,3 \\
\hline Toplam & 400 & 100,0 \\
\hline
\end{tabular}

Anket çalışmasına katılan park kullanıcılarının \%57,3'ü erkek, \%42,8'i kadın kullanıcılardan oluşmaktadır. Katılımcıların yaş gruplarına göre dağılımı Tablo 2' de gösterilmektedir. 
Tablo 2. Katılımcıların yaş gruplarına göre dağılımı

\begin{tabular}{lrr}
\hline Yaş Grubu & Kişi Sayısı & Yüzde(\%) \\
\hline $15-18$ & 25 & 6,3 \\
\hline $19-29$ & 65 & 16,3 \\
\hline $30-49$ & 102 & 25,5 \\
\hline $50-65$ & 126 & 31,5 \\
\hline $65<$ & 82 & 20,5 \\
\hline Toplam & 400 & 100,0 \\
\hline
\end{tabular}

Katılımcıların büyük çoğunluğunu $(\% 31,5)$ 'ini 50-65 yaş aralığındaki bireyler oluşturmaktadır. $\% 25,5$ oranında $30-49$ yaş aralığı ve \%20,5 oranında 65 yaş üstü bireyler yer almaktadır. Bu sonuçlar doğrultusunda genç bireylerin "Prof. Dr. Erdal İnönü Kent Parkı'na rağbet göstermediğinden söz edilebilir.

Katılımcıların eğitim durumu incelendiğinde, \%45,8 ile lise mezunları çoğunluktadır. Daha sonra \%28,5 ile lisans mezunları ve \%11,8 ile ön lisans mezunları gelmektedir. Katılımcılar arasında okur-yazar olmayan birey bulunmamaktadır. Ankete katılanların mesleki durumu incelendiğinde en fazla \%26,0 ile emekliler yer almaktadır. Onu \%24,8 ile özel sektör çalışanları takip etmektedir. Katılımcıların aylık gelir durumu incelendiğinde \%39,3 ile "14012800 TL" aralığı çoğunluktadır. Onu \%30.0 ile "Asgari ücret ve altı" seçeneği, \%22,5 ile "2800-4200 TL" seçeneği takip etmektedir. Katılımcıların ikamet ettiği ilçeler Tablo 3'de verilmiştir.

Tablo 3. Katılımcıların ikamet ettikleri ilçelere göre dağılımı

\begin{tabular}{lrr}
\hline \multicolumn{1}{c}{ İkamet Edilen İlçe } & Kişi Sayısı & Yüzde(\%) \\
\hline Muratpaşa & 294 & 73,5 \\
\hline Kepez & 49 & 12,3 \\
\hline Konyaaltı & 37 & 9,3 \\
\hline Aksu & 9 & 2,3 \\
\hline Döşemealtı & 6 & 1,5 \\
\hline Şehir Dışı & 5 & 1,3 \\
\hline Toplam & 400 & 100,0 \\
\hline
\end{tabular}

Katılımcıların ikamet ettiği ilçeler incelendiğinde büyük çoğunluğun $(\% 73,5)$ "Prof. Dr. Erdal İnönü Kent Parkı'nın yer aldığı Muratpaşa İlçesinde ikamet ettikleri tespit edilmiştir. Muratpaşa'yı \%12,3 ile Kepez, \%9,3 ile Konyaaltı İlçeleri takip etmektedir. Kent parkını ziyaret edenler arasında \% 2,3 oranında Aksu ve \% 1,5 oranında Döşemealtı ilçelerinde ikamet eden bireyler yer almaktadır. Katılımcıların kent parkına gitme amacı Tablo 4 'de yer almaktadır.

Tablo 4. Katılımcıların kent parkına gitme amaçlarının dağılımı

\begin{tabular}{lrc}
\hline \multicolumn{1}{c}{ Kent Parkına Gitme Amacı } & Kişi SayıSı & Yüzde(\%) \\
\hline Spor Yapmak & 33 & 8,3 \\
\hline Yeni İnsanlarla Tanışmak & 3 & 0,8 \\
\hline Manzara İzlemek & 34 & 8,5 \\
\hline Yalnız Kalmak & 17 & 4,3 \\
\hline Balık Tutmak & 4 & 1,0 \\
\hline Su Öğelerini İzlemek & 16 & 4,0 \\
\hline Ailece Vakit Geçirmek & 37 & 9,3 \\
\hline Güneşlenmek & 8 & 2,0 \\
\hline Sergi/Konser/Nikâh & 4 & 1,0 \\
\hline Dinlenmek & 78 & 19,5 \\
\hline
\end{tabular}

Tablo'4 ün devamı

\begin{tabular}{lcc}
\hline Vakit Geçirmek & 27 & 6,8 \\
\hline Evcil Hayvan Gezdirmek & 14 & 3,5 \\
\hline Çocuk Gezdirmek & 19 & 4,8 \\
\hline Temiz Hava Almak & 46 & 11,5 \\
\hline Piknik Yapmak & 13 & 3,3 \\
\hline Gazete/Dergi Okumak & 12 & 3,0 \\
\hline İnsanlarla Buluşmak & 35 & 8,8 \\
\hline
\end{tabular}


Katılımcıların "Prof. Dr. Erdal İnönü Kent Parkı'na gitme amaçları incelendiğinde \%19,5 oranıyla "Dinlenmek" seçeneği ilk sırada yer almaktadır. Ardından \%11,5 ile "Temiz hava almak" ve \%8,5 ile "manzara izlemek" gelmektedir.

\section{Park Kullanıcılarının Fonksiyonel Kriterler Doğrultusunda Görüşlerinin Tespit Edilmesi}

Çalışma kapsamında; yönlendirici, dinlendirici, kötü görüntü perdeleme özelliği var, iklim için uygun, yaşılar için uygun, engelliler için uygun, odak özelliği var olmak üzere toplam 7 adet fonksiyonel kriter tespit edilmiştir. Park içerisinde yer alan 9 kullanım bu kriterler doğrultusunda değerlendirilmiştir. En düşük "1" puan, en yüksek "5" puan olacak şekilde her bir kullanımın fonksiyonel kriterler açısından aldıkları ortalama puanlar tespit edilmiştir. Her bir kullanımın almış oldukları puanlar Arc - MAP 10.1 yazılımına işlenmiş ve "kriging yöntemi" kullanılarak fonksiyonel kriterlerin haritası oluşturulmuştur. Oluşturulan harita Şekil 4'de verilmiştir. Katılımcıların her bir kullanım için " 1 " en düşük puan (hiç beğenmiyorum), " 5 " en yüksek puan (çok beğeniyorum) vermiş oldukları puanlar Tablo 5'de verilmiştir.

Tablo 5. Kullanıcı görüşleri doğrultusunda fonksiyonel kriterlerin almış oldukları puanlar

\begin{tabular}{|l|c|c|c|c|}
\hline \multicolumn{1}{|c|}{ KRİTERLER } & MİN. & MAX. & ORTALAMA & STANDART SAPMA \\
\hline Yönlendirici & 3,27 & 4,48 & 3,875 & 1,185 \\
\hline Dinlendirici & 3,46 & 4,50 & 3,980 & 1.780 \\
\hline Perdeleme Öz. Var & 3.18 & 4,37 & 3,775 & 1,021 \\
\hline İklim İçin Uygun & 3,02 & 4,23 & 3,625 & 1,321 \\
\hline Yaşlılar İçin Uygun & 3,01 & 4,20 & 3,605 & 1,457 \\
\hline Engelliler İçin Uygun & 3,01 & 4,00 & 3,505 & 1,574 \\
\hline Odak Özelliği Var & 3,13 & 4,53 & 3,830 & 1,541 \\
\hline 1: Hiç Beğenmiyorum 2: Beğenmiyorum 3: Fikrim Yok 4: Beğeniyorum 5:Çok Beğeniyorum \\
\hline
\end{tabular}

Her bir kullanım alanı için belirlenen fonksiyonel kriterler doğrultusunda puanlamalar yapılmıştır. "Yönlendirici" kriteri için "4,48" en yüksek puan ortalaması, "3,22" en düşük puan ortalamasını ifade etmektedir. "Dinlendirici" kriteri için "4,50" en yüksek puan ortalaması, "3,46" en düşük puan ortalamasını ifade etmektedir. "Perdeleme özelliği var" kriteri için. "4,37" en yüksek puan ortalaması, "3,18" en düşük puan ortalamasını ifade etmektedir. "İklim için uygun" kriteri için "4,23" en yüksek puan ortalaması, "3,02" en düşük puan ortalamasını ifade etmektedir. "Yaşlılar için uygun" kriteri için "4,20" en yüksek puan ortalaması, "3,01" en düşük puan ortalamasını ifade etmektedir. "Engelliler için uygun" kriteri için " 4,00 " en yüksek puan ortalaması, "3,01" en düşük puan ortalamasını ifade etmektedir. "Odak özelliği var" kriteri için "4,53" en yüksek puan ortalaması, "3,13" en düşük puan ortalamasını ifade etmektedir.

Kullanıcılara yöneltilen değerlendirme formunda yer alan fonksiyonel kriterler Arc-MAP 10.1 yazılımında bulunan kriging yöntemi kullanılarak tek harita üzerinde görselleştirilmiştir. Her bir kullanım alanı için verilen puanların ortalamaları alanlara işlenmiştir. Yönlendirici, dinlendirici, kötü görüntü perdeleme, iklim için uygun, yaşlılar için uygun, engelliler için uygun ve odak(buluşma özelliği var) kriterlerine verilen puanlar toplanarak "7-35" (7 kriter en yüksek 1 puan, en düşük 5 puan 7x1 - 7x5) puan aralığı üzerinden "22,19-30,03" aralığında bir sonuç elde edilmiştir. 30,03 en yüksek puan toplamını, 22,19 en düşük puanını temsil edecek şekilde oluşturulan harita Şekil 5'de görüntülenmektedir. 


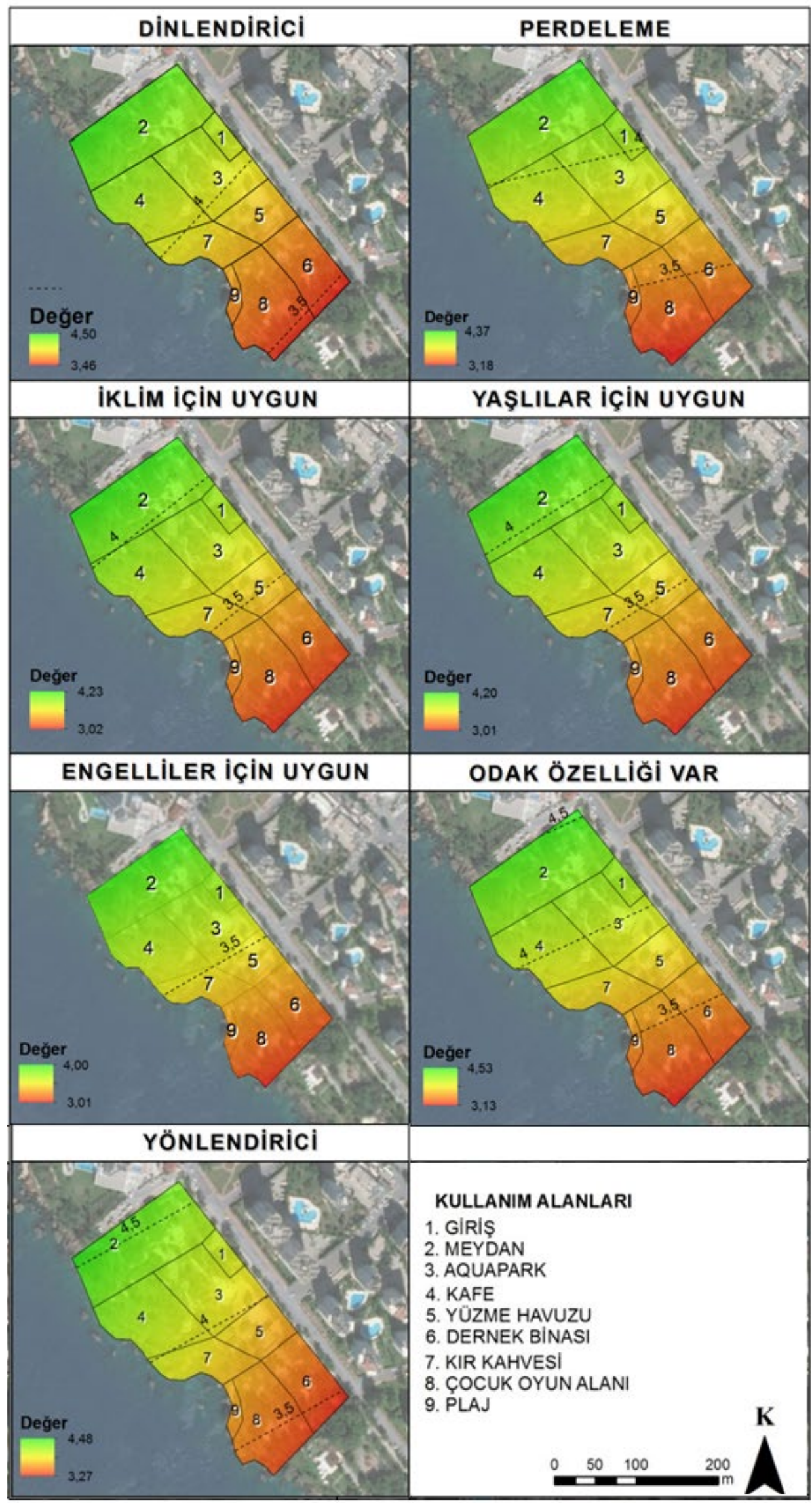

Şekil 4. Kullanıcı görüşleri doğrultusunda fonksiyonel kriterlerin haritaları 


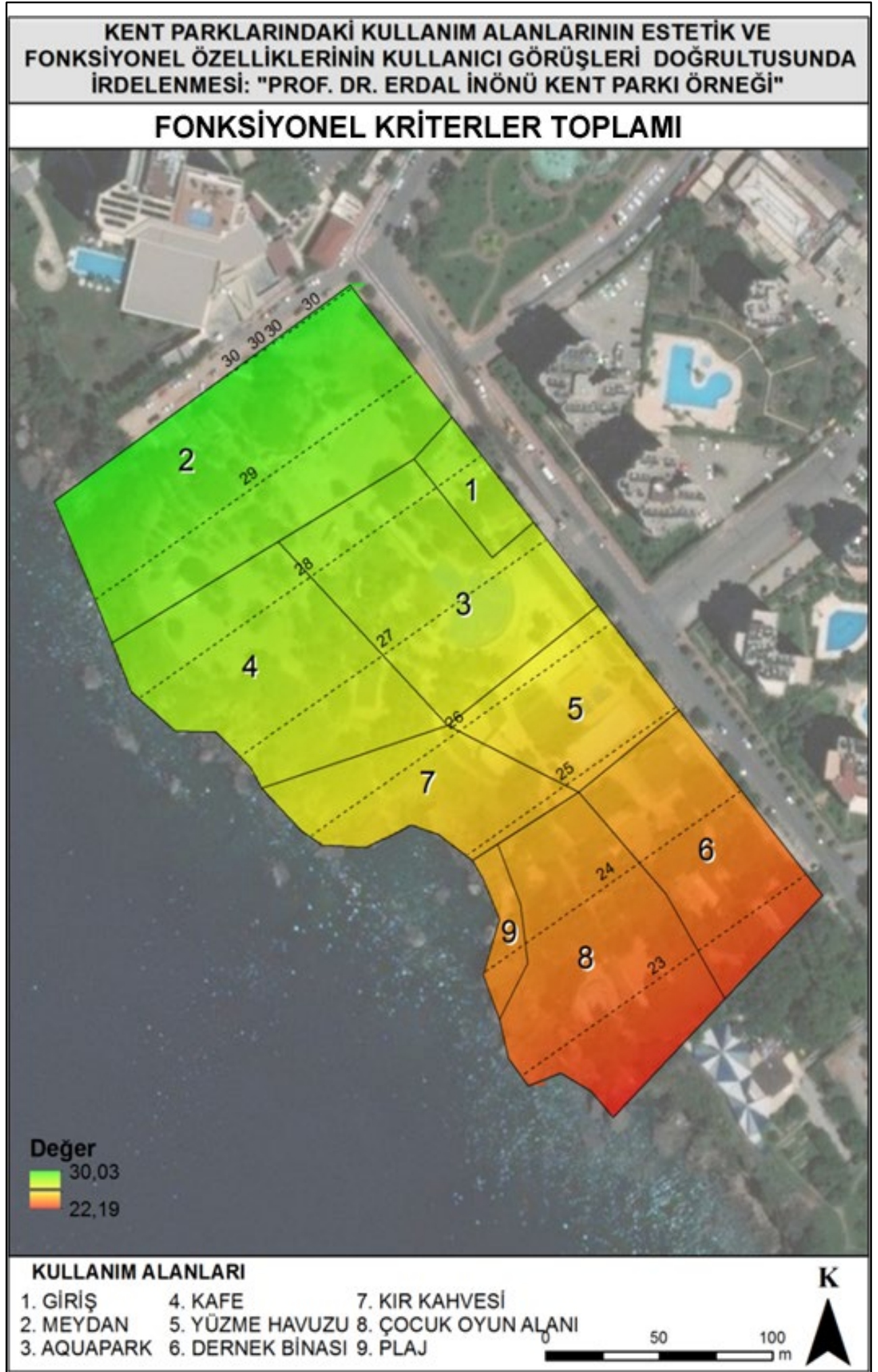

Şekil 5. Kullanıcı görüşleri doğrultusunda fonksiyonel kriterlerinin toplam puan haritası

\section{Park Kullanıcılarının Estetik Kriterler Doğrultusunda Görüşlerinin Tespit Edilmesi}

Çalışma kapsamında; çekici, güzel, bakımlı, çevreyle uyumlu, doğal, görkemli, şaşırtıcı, hareketli, geometrik, ferahlatıcı, büyük olmak üzere toplam 11 adet estetik kriter tespit edilmiştir. Estetik kriterler de fonksiyonel kriterler gibi bir puanlama sistemi ile park içerisindeki kullanımların almış oldukları toplam puanlar tespit edilmiştir. En düşük " 1 " puan, en yüksek " 5 " puan olacak şekilde her bir kullanımın estetik kriterler doğrultusunda aldıkları ortalama puanlar tespit edilmiştir. Her bir kullanımın almış oldukları puanlar Arc - MAP 10.1 
yazılımına işlenmiş ve "kriging yöntemi" kullanılarak fonksiyonel kriterlerin haritası oluşturulmuştur. Katılımcıların her bir kullanım için "1" en düşük puan (hiç beğenmiyorum), "5" en yüksek puan (çok beğeniyorum) vermiş oldukları puanlar Tablo 6'de verilmiştir.

Tablo 6. Kullanıcı görüşleri doğrultusunda estetik kriterlerin almış oldukları puanlar

\begin{tabular}{|l|c|c|c|c|}
\hline \multicolumn{1}{|c|}{ KRİTERLER } & MİN. & MAX. & ORTALAMA & STANDART SAPMA \\
\hline Çekici & 3,00 & 4,62 & 3,810 & 1,452 \\
\hline Güzel & 3,07 & 4,54 & 3,805 & 1,875 \\
\hline Çevreyle Uyumlu & 3,35 & 4,68 & 4,015 & 1,236 \\
\hline Bakım & 3,36 & 4,40 & 3,880 & 1,657 \\
\hline Doğal & 3,33 & 4,44 & 3,885 & 1,874 \\
\hline Görkem & 3,33 & 4,61 & 3,970 & 1,574 \\
\hline Hareketli & 3,40 & 4,36 & 3,880 & 1,964 \\
\hline FerahlatıCı & 3,29 & 4,52 & 3,905 & 1,364 \\
\hline Geometrik & 3,43 & 4,30 & 3,865 & 1,012 \\
\hline Şaşırtıcı & 3,29 & 4,52 & 3,905 & 1,325 \\
\hline Büyük & 3,36 & 4,38 & 3,870 & 1,274 \\
\hline 1: Hiç Beğenmiyorum 2: Beğenmiyorum 3: Fikrim Yok 4: Beğeniyorum 5: Çok Beğeniyorum \\
\hline
\end{tabular}

Her bir kullanım alanı için belirlenen estetik kriterler doğrultusunda puanlamalar yapılmıştır. "Çekici" kriteri için "4,62" en yüksek puan ortalaması olurken, "3,00" en düşük puan ortalaması olmuştur. Eş yükselti eğrileri üzerindeki noktalar aynı frekans (sıklık analizi) değerini ifade edecek şekilde oluşturulan haritalar incelendiği zaman, kent parkı girişinin 4,6 üzerinde bir ortalamaya sahip olduğu anlaşılmaktadır. Alanın iç kısımlarına doğru gidildikçe bu ortalamanın 4.0'e kadar düştüğü, alanın güneyinde yer alan çocuk oyun alanı ve plaj çevresinde ise ortalama 3,5'e kadar düşmektedir. Alanın doğusunda yer alan dernek binası ve çevresinde ortalama 3.0'e kadar düşmektedir.

"Güzel" kriteri için "4,54" en yüksek puan ortalaması, "3,07" en düşük puan ortalaması olacak şekilde oluşturulan haritalar incelendiği zaman, kent parkı girişinin 4,5 üzeri bir ortalamaya sahip olduğu anlaşılmaktadır. Park meydanı, aquapark çevresi ve yüzme havuzu çevresinde 4.0'ün üzerinde bir ortalama hâkimken; dernek çevresi, çocuk oyun alanı ve plaj çevresinde ortalama 3,5'in altındadır. Park içerinde bulunan plaj Şekil 6'da verilmiştir.

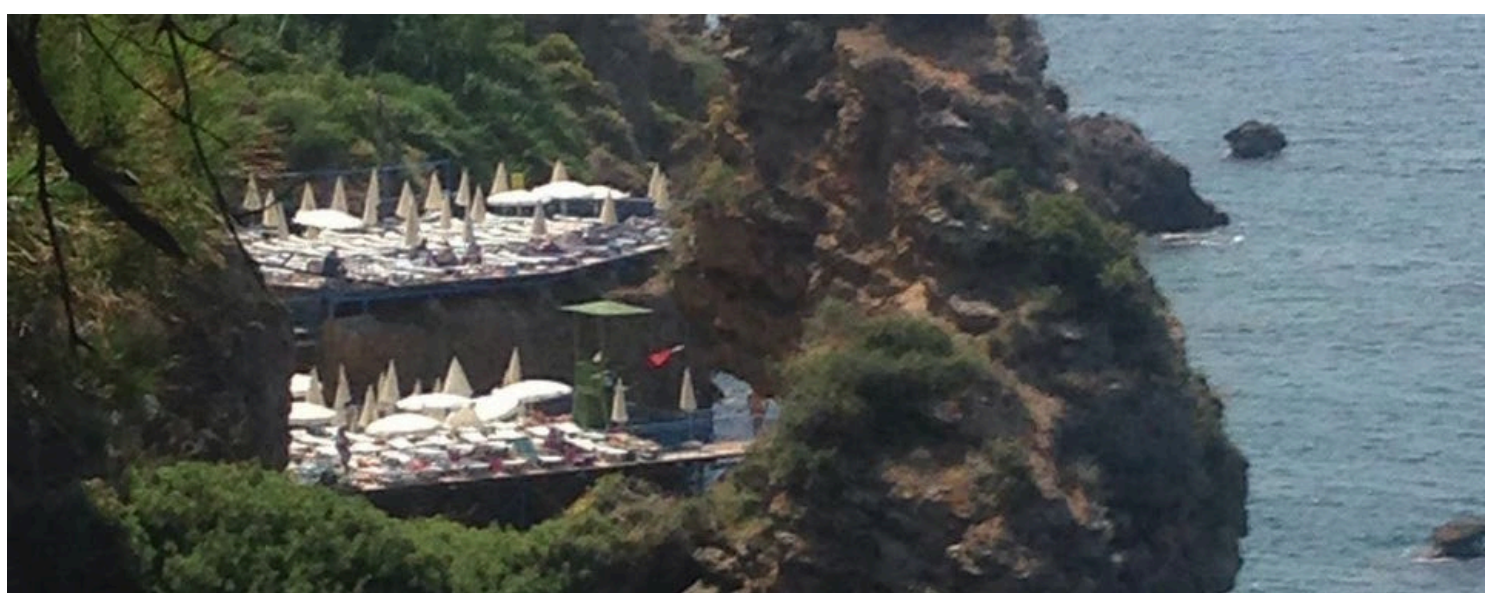

Şekil 6. Park içerisinde bulunan plaj alanı

"Çevreye uyumlu" kriteri için kullanıcıların verdiği puanlar çalışma alanında yer alan dokuz kullanım alanına dağılımı gerçekleştirilmiştir. "4,68" en yüksek puan ortalaması, "3,35" en düşük puan ortalaması olacak şekilde oluşturulan haritalar incelendiği zaman, park meydanının 4,5 üzeri bir ortalamaya sahip olduğu anlaşılmaktadır.

"Doğal" kriteri için kullanıcıların verdiği puanlar çalışma alanında yer alan dokuz kullanım alanına dağılımı gerçekleştirilmiştir. "4,44" en yüksek puan ortalaması, "3,33" en düşük puan ortalaması olacak şekilde oluşturulan haritalar incelendiği zaman, park meydanı, park girişi ve aquapark çevresi 4 üzeri bir ortalamaya sahip olduğu anlaşılmaktadır. Dernek binası çevresi ve çocuk oyun alanı 3,5 civarında bir ortalamaya sahiptir.

"Bakımı" kriteri için kullanıcıların verdiği puanlar çalışma alanında yer alan dokuz kullanım alanına dağılımı gerçekleştirilmiştir. "4,40" en yüksek puan ortalaması, "3,36" en düşük puan 
ortalaması olacak şekilde oluşturulan haritalar incelendiği zaman, park meydanı, park girişi ve aquapark çevresi 4.0 üzeri bir ortalamaya sahip olduğu anlaşılmaktadır. Dernek binası çevresi ve çocuk oyun alanı 3,5 civarında bir ortalamaya sahiptir.

"Görkemli" kriteri için kullanıcıların verdiği puanlar çalışma alanında yer alan dokuz kullanım alanına dağılımı gerçekleştirilmiştir. "4,61" en yüksek puan ortalaması, "3,33" en düşük puan ortalamasını ifade etmektedir. "Hareketli" kriteri için "4,36" en yüksek puan ortalaması, "3,40" en düşük puan ortalamasını ifade etmektedir. "Ferahlatıcı" kriteri için "4,52" en yüksek puan ortalaması, "3,29" en düşük puan ortalamasını temsil etmektedir. "Geometrik" kriteri için "4,30" en yüksek puan ortalaması, "3,43" en düşük puan ortalamasını ifade etmektedir. "Şaşırtıcı" kriteri için "4,52" en yüksek puan ortalaması, "3,29" en düşük puan ortalamasını ifade etmektedir. "Büyük" kriteri için "4,38" en yüksek puan ortalaması, "3,38" en düşük puan ortalamasını ifade etmektedir.

Park girişi, aquapark çevresi ve yüzme havuzu çevresinde 4.0'ün üzerinde bir ortalama hakimken; dernek çevresi, çocuk oyun alanı ve plaj çevresinde ortalama 3,5'e kadar düşmektedir. Kriging yöntemi kullanılarak estetik kriterler için oluşturulan haritalar Şekil 7, Şekil 8' de verilmiştir.

Kullanıcılara yöneltilen değerlendirme formunda yer alan estetik kriterler Arc-MAP 10.1 yazılımında bulunan kriging yöntemi kullanılarak tek harita üzerinde görselleştirilmiştir. Her bir kullanım alanı için verilen puanların ortalamaları alanlara işlenmiştir. Çekici, güzel, doğal, bakımlı, çevreye uyumlu, görkemli, şaşırtıcı, hareketli, geometrik, ferahlatıcı ve büyük kriterlerinden oluşan 11 tane estetik kriterlere verilen puanlar toplanarak "11-55" (11 kriter en yüksek 1 puan, en düşük 5 puan $11 \times 1$ - 11x5) puan aralığı üzerinden "36,88-48,55" aralığında bir sonuç elde edilmiştir. 48,55 en yüksek puan toplamını, 36,88 en düşük puan toplamını temsil edecek şekilde oluşturulan harita Şekil 9'de görüntülenmektedir.

\section{Ki-kare Bağımsızlık Testleri}

Katılımcıların anket çalışmasındaki sorulara verdikleri yanıtların, demografik özelliklerine göre anlamlı bir şekilde farklılıklar gösterip göstermediğini saptamak için ki-kare bağımsızlık testleri yapılmıştır. Yaş değişkenine göre kullanıcıların verdiği puanların farklılık gösterip göstermediği Tablo 7'de ifade edilmektedir.

Tablo 7. Kullanıcı tercihlerinin yaşa göre farklılık gösterme durumu

\begin{tabular}{|c|c|c|c|c|c|c|c|c|c|c|}
\hline \multirow[b]{2}{*}{ YAŞ } & \multirow[b]{2}{*}{ SAYI } & \\
\hline & & Giriş & Meydan & $\begin{array}{c}\text { Kır } \\
\text { Kahvesi }\end{array}$ & Aquapark & $\begin{array}{c}\text { Yüz. } \\
\text { Havuzu }\end{array}$ & Kafe & Dernek & Ç.O.A & Plaj \\
\hline CEKİCİ & 400 & 0.012 & 0.016 & 0.038 & 0.013 & 0.016 & 0.021 & 0.002 & 0.040 & 0.012 \\
\hline GÜZEL & 00 & 0.025 & 0.012 & 0.025 & 0.002 & 0.006 & 0.024 & 0.048 & 0.040 & 0.010 \\
\hline DOĞAL & 00 & 0.035 & 0.022 & 0.040 & 0.041 & 0.007 & 0.042 & 0.018 & 0.007 & 0.028 \\
\hline BAKIMLI & 5 & 0.018 & .026 & 0.002 & & 0.026 & 0.014 & 16 & 0.021 & 0.032 \\
\hline $\begin{array}{l}\text { ÇEVREYE } \\
\text { UYUMLU }\end{array}$ & 400 & 0.041 & 0.036 & 0.043 & 0.005 & 0.047 & 0.018 & 0.047 & 0.012 & 0.006 \\
\hline GÖRKEMLİ & 400 & 0.008 & 0.014 & 0.021 & 0.002 & 0.040 & 0.041 & 0.036 & 0.020 & 0.007 \\
\hline ŞAŞIRTICI & 400 & 0.003 & 0.023 & 0.024 & 0.048 & 0.040 & 0.027 & 0.026 & 0.011 & 0.026 \\
\hline HAREKETLİ & 400 & 0.007 & 0.038 & 0.042 & 18 & 0.077 & 0.027 & 0.022 & 0.014 & 0.047 \\
\hline GEOMETRİK & 4 & .006 & 4 & 0.014 & U & 0.021 & 0.029 & 447 & 0.012 & 0.022 \\
\hline FERAHLATICI & 4 & .010 & 221 & 0.018 & 47 & 0.012 & 0.014 & 0.032 & 0.026 & 0.017 \\
\hline BÜYÜK & 400 & 0.033 & 0.044 & 0.041 & 0.036 & 0.320 & 0.022 & 0.026 & 0.012 & 0.023 \\
\hline YÖNLENDİRİCİ & 400 & .003 & 36 & 0.027 & 26 & 0.011 & 0.001 & 0.045 & 0.018 & 0.036 \\
\hline DİNLENDİRİCİ & 400 & .004 & 019 & 0.026 & 0. & 0.272 & 0.028 & 0.015 & 0.022 & 0.011 \\
\hline PERDELEME & 400 & .039 & .021 & 0.046 & 8 & 0.017 & 0.026 & 14 & 0.027 & 0.029 \\
\hline $\begin{array}{l}\text { İKLİM İÇİN } \\
\text { UYGUN }\end{array}$ & 00 & 0.001 & 06 & 0.026 & & 0.002 & 0.011 & & 0.012 & 0.001 \\
\hline $\begin{array}{l}\text { YAŞLILARA } \\
\text { UYGUN }\end{array}$ & 400 & 0.014 & 16 & 0.018 & 25 & 0.026 & 0.036 & 47 & 0.026 & 0.001 \\
\hline $\begin{array}{c}\text { ENGELLİLERE } \\
\text { UYGUN }\end{array}$ & 400 & 0.036 & 0.025 & 0.022 & 0.024 & 0.045 & 0.047 & 0.036 & 0.045 & 0.001 \\
\hline $\begin{array}{c}\text { ODAK } \\
\text { ÖZELLİĞİ VAR }\end{array}$ & 400 & 0.028 & 0.039 & 0.012 & 0.034 & 0.021 & 0.022 & 0.028 & 0.031 & 0.00 \\
\hline
\end{tabular}




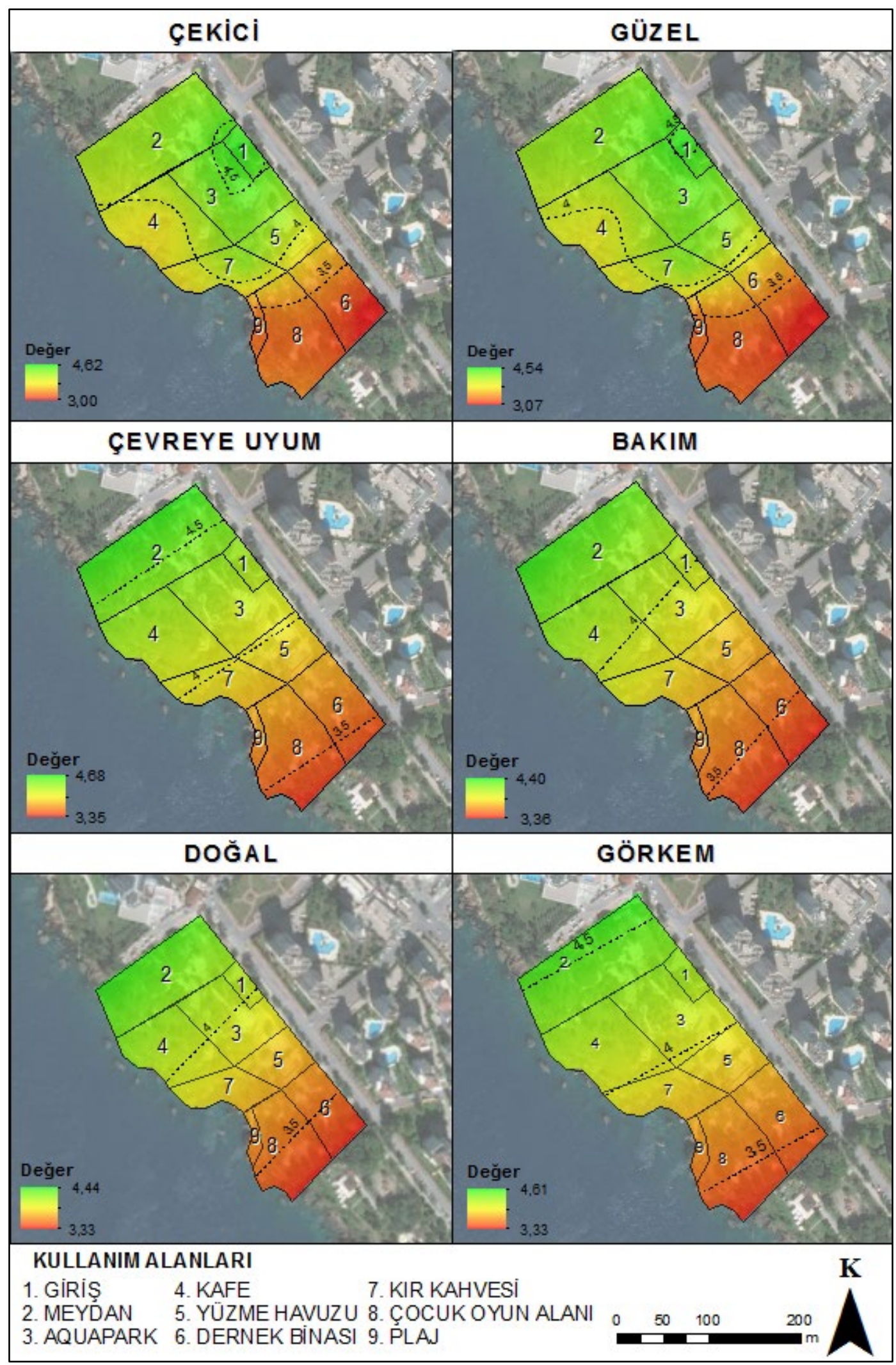

Şekil 7. Kullanıcı görüşleri doğrultusunda estetik kriterlerin haritaları 1 


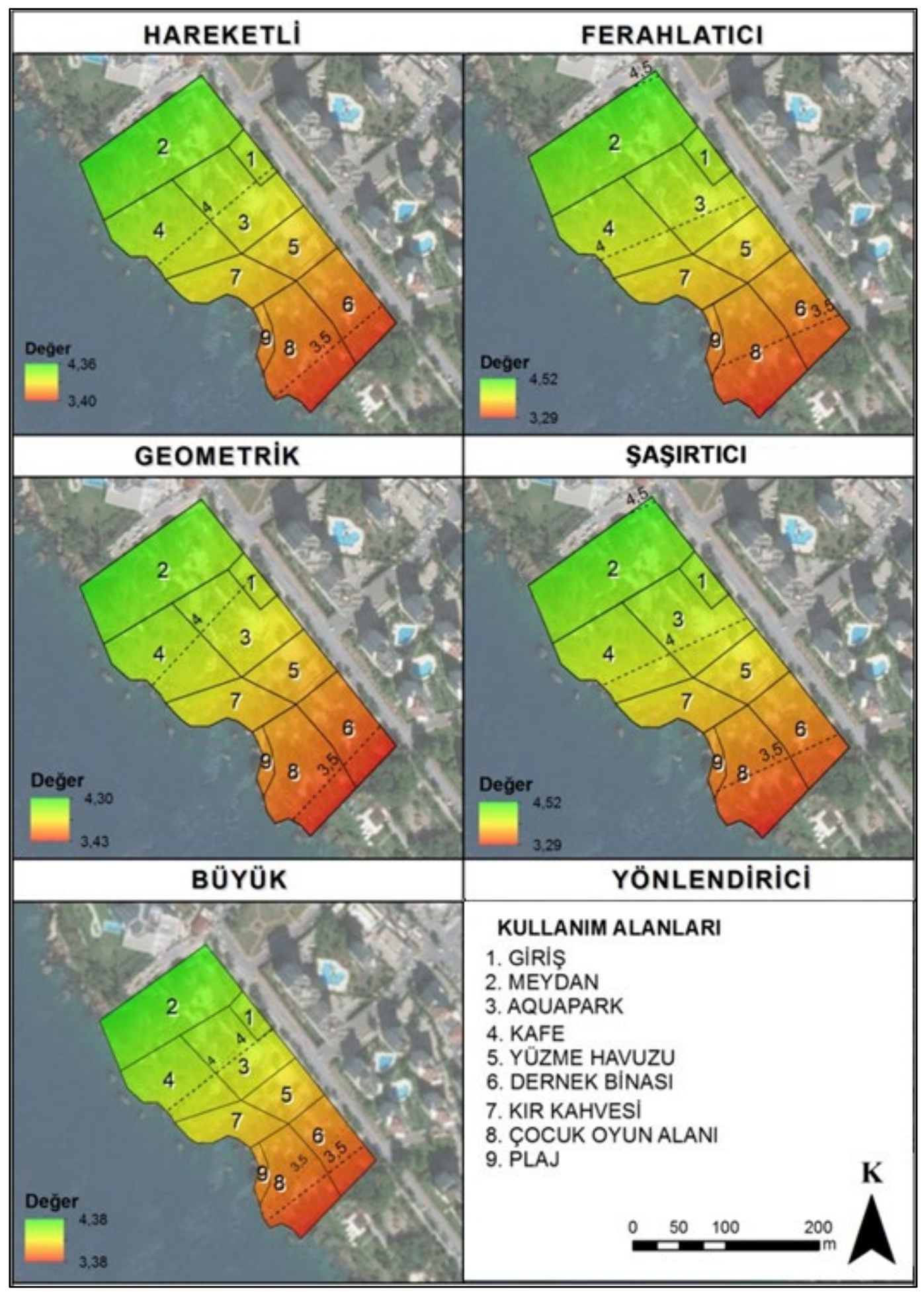

Şekil 8. Kullanıcı görüşleri doğrultusunda estetik kriterlerin haritaları 2 


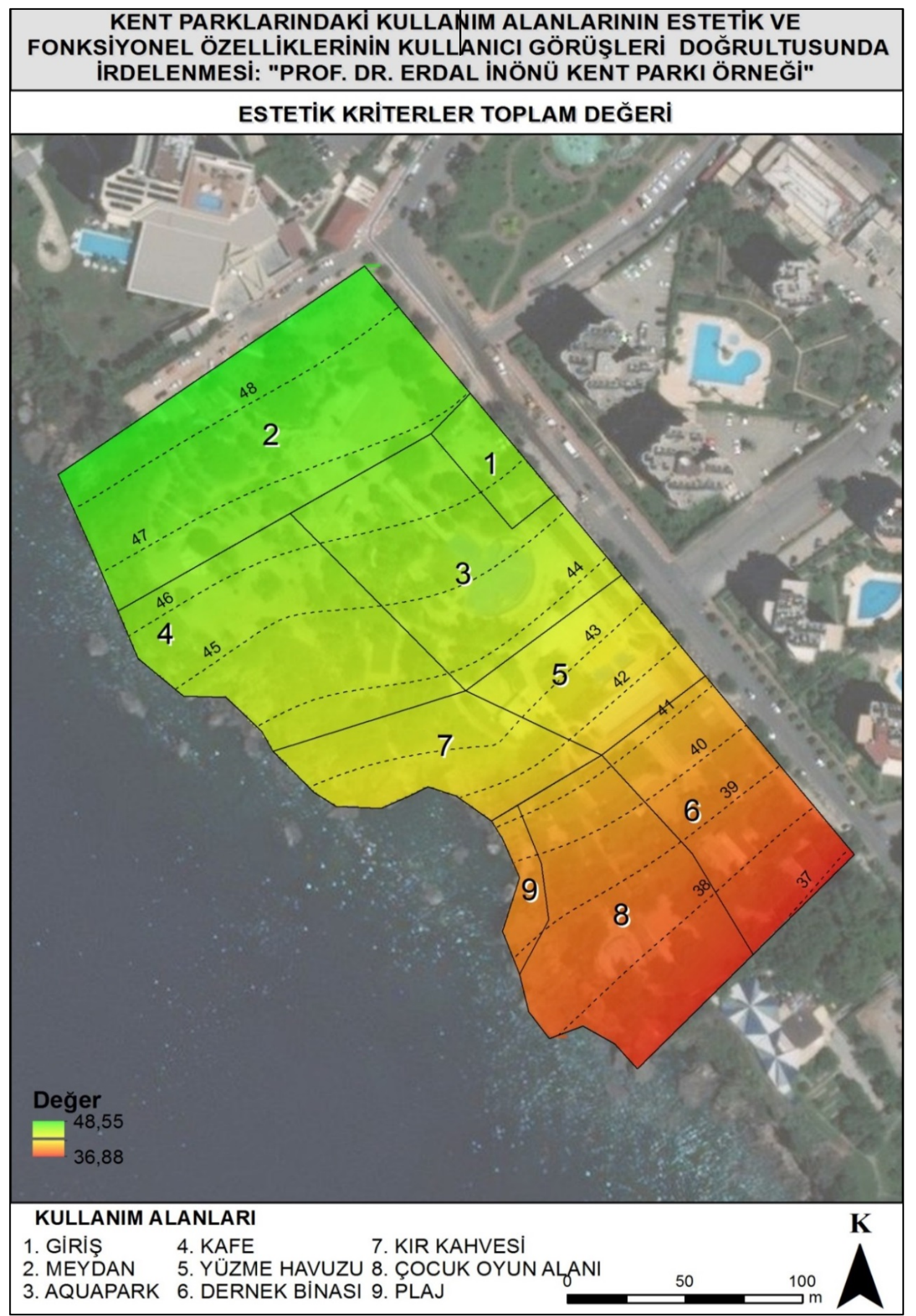

Şekil 9. Kullanıc görüşleri doğrultusunda estetik kriterlerinin toplam puan haritası 
Tablo 7'de de görüldüğü gibi 162 sorunun tamamı $p<0.05$ olduğundan dolayı estetik ve fonksiyonel kriterlerin yaş değişkenine bağlı olarak farklılık gösterdiği anlaşılmaktadır.

Park girişi için geometrik, büyük, iklim için uygun, yaşlılara uygun, odak özelliği var; park meydanı için doğal, bakımlı, görkemli, yönlendirici, engellilere uygun, odak özelliği var; kır kahvesi ve çevresi için çekici, güzel, çevreye uyumlu, görkemli, şaşırtıcı, hareketli, geometrik, dinlendirici, iklim için uygun, yaşlılar için uygun, engellilere uygun, odak özelliği var; aquapark için bakımlı, geometrik, büyük, iklim için uygun, yaşlılara uygun; yüzme havuzu için doğal, bakımlı, dinlendirici, yaşlılar için uygun, engellilere uygun; kafe için güzel, bakımlı, görkemli, geometrik; dernek binası için doğal, bakımlı, çevreye uyumlu, görkemli şaşırtıcı, geometrik, ferahlatıcı, iklim için uygun, yaşlılara uygun, engellilere uygun, odak özelliği var; çocuk oyun alanı için çekici, güzel, çevreye uyumlu, ferahlatıcı, büyük, yönlendirici, dinlendirici, odak özelliği var; plaj için yaşlılara uygun, engellilere uygun ve odak özelliği var seçeneklerinde $p<0.05$ sağlandığından dolayı anlamlı farklılık gözlenmektedir.

Kullanıcı tercihlerinin mesleğe göre farklılık gösterip göstermediği incelendiğinde toplam 162 sorunun 145'inde anlamlı farklılık gözlenmektedir. Kent parkı girişi için çekici, güzel, çevreye uyumlu, görkemli, iklim için uygun; kent parkı meydanı için çekici, dinlendirici, perdeleme özelliği var, iklim için uygun; aquapark için engellilere uygun ve odak özelliği var; dernek binası için hareketli, büyük, dinlendirici; çocuk oyun alanı için çekici, güzel ve görkemli kriterlerinde anlamlı farklılık gözlenmemektedir.

Yaş, cinsiyet, meslek, gelir ve eğitim değişkenlerine bağlı olarak kullanıc tercihlerinin anlamlı farklılık gösterme durumu Tablo 8 'de gösterilmektedir.

Tablo 8. Kullanıcı tercihlerinin anlamlı farklılık gösterme oranı

\section{DEĞİŞKEN TOPLAM SORU ANLAMLI FARKLILIK GÖSTEREN (q<0.05) ORAN (\%)}

\begin{tabular}{cccc}
\hline Yaş & 162 & 162 & 100 \\
\hline Meslek & 162 & 145 & 90 \\
\hline Gelir & 162 & 137 & 85 \\
\hline Eğitim & 162 & 94 & 58 \\
\hline Cinsiyet & 162 & 61 & 38 \\
\hline
\end{tabular}

Cinsiyet değişkenine göre kullanıcıların verdiği yanıtlar incelendiğinde anket formunda yer alan 162 sorunun 61'inde anlamlı farklılık gösterdiği anlaşılmaktadır. Kullanıcı tercihlerinin eğitim durumuna göre anlamlı farklılık gösterip göstermediği incelendiğinde toplam 162 sorunun 94'ünde anlamlı farklılık görülmektedir. Meslek gruplarına göre bakıldığında ise; 145 seçenekte anlamlı farklılık olduğu tespit edilmiştir. Kullanıc tercihlerinin gelir durumuna göre dağılımı incelendiğinde 162 sorunun 137'sinde anlamlı farklılık gözlenmektedir. Buna göre anket formunda yer alan soruların tamamı yaş değişkenine göre \%100 oranında anlamlı farklılık göstermektedir. Bu oran meslek seçeneğinde \%90, gelir durumunda \%85, eğitim durumunda \%58 oranında anlamlı farklılık göstermektedir. En az anlamlı farklılık ise \%38 oranıyla cinsiyette görülmektedir.

\section{TARTIŞMA VE SONUÇ}

Kent parkları, sahip oldukları yeşil alanlar ile bulundukları mekâna çok fazla sayıda katkıda bulunurlar. Ancak kent parklarının kullanıcılar tarafından fazla tercih edilmesi için kent parklarının iyi bir planlama ve tasarım süreci geçirmiş olması gerekmektedir. Yapılacak tasarımının ekonomik, ekolojik ve fonksiyonel olması parkın kullanımını etkileyen temel nedenler olarak sıralanabilir. Ekolojik ve ekonomik fonksiyonlar için sadece çalışma alanı ile sınırlı kalmayıp, yakın çevrenin de analiz edilmesi gerekmektedir. Ayrıca arazi gözlemleri ne nicel verilerin kullanılması (ölçme, analiz vb.) gerekmektedir. Böyle bir çalışma kapsamında olmadığından dolayı sadece parkların estetik ve fonksiyonel kriterler doğrultusunda değerlendirilmesine çalışılmıştır.

Çalışma kapsamında Antalya İli Muratpaşa İlçesinde bulunan "Prof. Dr. Erdal İnönü Kent Parkı" içerisinde bulunan kullanımların estetik ve fonksiyonel kriterleri, kullanıcı görüşleri doğrultusunda değerlendirilmiştir. Çalışma alanı içerisinde bulunan kullanım alanlarının birbiriyle yakın olması gereken kullanımların uzak olarak tasarlandığı tespit edilmiştir. Örneğin çocuk oyun alanı ve ailelerin çoğunlukla tercih ettikleri oturma alanları, kafe, meydan vb. alanların arazi gözlemleri sonucunda birbiriyle ilişkili bir şekilde tasarlanmadığı tespit edilmiştir. Ayrıca parka içerisinde peyzaj tasarımının temel unsurlarından olan kitleboşluk ilişkisinin düşünülmediği yapılan arazi gözlemleri sonucunda tespit edilmiştir. Birbirine 
yakın olması gereken kır bahçesi ve oyun alanları gibi kullanımların yakın olmadığı bunun sonucunda da özellikle çocuklu ailelerde güvenlik probleminin oluştuğu tespit edilmiştir. Arazi gözlemleri sonucunda alan içerisinde bulunan diğer kullanım alanlarının alan içerisinde yönlendirici ya da kötü görüntü bulunan alanlarda perdeleme özelliğinin olması gerekmektedir. Çalışma kapsamında incelenen parkta kullanımların bu özellikleri dikkate alınarak tasarlanmadığı tespit edilmiştir. Bu sebeplerden dolayı kullanıcılar üzerinden yapılan anket çalışmasının sonuçlarına göre; estetik ve fonksiyonel kriterlere verilen puanların ortalamaların 3,0 (fikrim yok) 3,5 puan olduğu tespit edilmiştir. Bunun sonucunda park içerisindeki kullanım alanlarının kullanıcılar tarafından fazla beğenilmediği söylenebilir.

Kullanıcılar üzerinde yapılan anket çalışması sonuçlarına göre park içerisinde bulunan kullanımların estetik kriterlerin dikkate alındığı söylenebilir. Yapılan anket çalışması sonucunda "çevreyle uyum kriterinin puan ortalamasının "4,0" olduğu, diğer alanlarda ise 3,5 puan ortalamasının üstünde olduğu tespit edilmiştir. Anket çalışması sonucunda 11 estetik kriter için puan ortalamasının 4,0 puanına yakın olmasından dolayı kullanıcıların parkı estetik kriterler doğrultusunda uygun buldukları söylenebilir. Bu beğeni durumunun sadece estetik kriterler açısından değil fonksiyonel kriterler açısından da benzer olduğunu söyleyebiliriz. Fonksiyonel kriterler doğrultusunda kullanım alanlarının ortalama puanının 4,0 yakın olduğu tespit edilmiştir. Anket katılanların vermiş oldukları puanların 4,0'a yakın olmasından dolayı park içerisindeki kullanım alanlarının fonksiyonel kriterler açısından uygun olduğu tespit edilmiştir. Bunun sonucunda da yapılan parklarda bulunan kullanımların estetik ve fonksiyonel kriterlerinin kullanıcılar tarafından beğenildiği tespit edilmiştir.

Bugüne kadar yapılmış olan çalışmalar değerlendirildiğinde, kullanıcıların parkların açık ve yeşil alanların yaşam kalitesine katkıları üzerine çalışmalar yaptıkları tespit edilmiştir. Karakaya (2019:1-2) "Yaşam Kalitesinin Arttırılmasında Kent Parklarının Önemi: Eskişehir İli Örneğinde İncelenmesi" isimli çalışmasında Eskişehir kentinde bulunan Sazova Bilim Kültür ve Sanat Parkı ve Kentpark örnekleminde yeşil alan ağının önemli bir parçası olan kent parkının, yaşam kalitesi üzerine olan etkilerini incelemiştir. Ayrıca çalışmalarda kent parkları içerisinde bulunan donatı elemanlarının (aydınlatma, çöp kutusu, bank vb.) yeterlilikleri tespit edilmiştir. Bayazıt (2018: 3-4) "Kentsel Donatı Elemanlarının Kent Kimliği Ve Estetik Değerler Yönünden İncelenmesi: Trabzon Ve Hükümet Caddeleri Örneği" isimli çalışmasında; Trabzon ve Hükümet Bulvarları üzerinde yer alan kentsel donatı elemanlarının kent kimliği ve estetiği açısından, peyzaj mimarlığı bakış açısıyla değerlendirmiştir. Kayha (2018: 5-6) Sakarya Kent Park Ve Sakarya Park Örneklerinde Kullanıcı Memnuniyeti Ve Kalite Karşılaştırması" isimli çalışmasında kent parkların, doğal ve kültürel dokusunun irdelenip, korunarak bakımının sağlanması, kent halkının açık alan gereksiniminin karşılanmasına ne derece yardımcı olduğunun belirlenmesi ile sürdürülebilir kullanımlarının kalite kriterleri doğrultusunda ele alınmasına yönelik öneriler getirmiştir. Yapılan çalışma yöntem açısında bu çalışma ile benzerlik göstermektedir. Park içerisinde bulunan kullanımların neler olması gerektiği ve bu kullanımlar arasındaki ilişkinin nasıl olması gerektiğinin tespit edilmesi açısından yapılan çalışmaların yetersiz kaldığı söylenebilir. Kent parklarının kentsel doku üzerine katkıları bulunmaktadır. Ancak bu mekânların sürdürülebilirliği kullanıcıların kullanım durumuna bağlıdır. Kentlere önemli katkıları bulunan "kent parklarının" kullanıcı görüşleri alınarak planlama ve tasarım yapılması kullanıcı tercihlerini artıracaktır.

Güreşçioğlu ve Demirin (2019: 38-51) "Düzce Melensu Parkı'nın Kullanıcı Memnuniyeti Açısından Değerlendirilmesi" isimli çalışmasında; Melensu parkının fonksiyonel, ekolojik ve estetik kriterler açısından uzmanlar üzerinden yapmış olduğu çalışma sonucunda alanda fonksiyonel kriterler açısından kısıtlamaların bulunduğu, bu kısıtlamaların giderilmesi amacıyla park içerisindeki kullanım ve aktivite sayılarının artırılması gerektiği tespit edilmiştir. Yapılan bu çalışma da ise park içerisinde bulunan kullanım ve aktivite sayısının yeterli olduğu, ancak bu kullanım alanlarının fonksiyonel ve estetik kriterler doğrultusunda geliştirilmesinin uygun olacağı tespit edilmiştir. Yıldırım (2011) çalışmasında kullanıcı gözlemlerini baz almıştır. Akyol (2006) çalışmasında kent mobilyalarının tasarım ve kullanım süreçlerinin tespiti için tasarım kriterleri ile gözlem sonuçlarını temel almıştır. Ghorab (2015) ise kentsel donatıları estetik tasarım kriterlerine göre değerlendirmiştir. Çalışmalarda anket yöntemi ile değerlendirmeler yapılmıştır. Bu çalışma kullanılan yöntem açısından farklılıklar içermektedir. Ancak Bayazıt (2018), Yıldırım (2011), Akyol (2006) ve Ghorab (2015) ile bu çalışma ile arasında sonuçlar açısından benzerlikler bulunmaktadır. Söz konusu çalışmalar ile bu çalışma arasında parkların fonksiyonelliği ve estetik kriterlere göre değerlendirilmesi noktasında benzerlik bulunmaktadır.

Yapılan arazi gözlemleri sonucunda park içerisinde bulunan kullanımlara yönelik kullanıcılar tarafından tercih edilmeyen ya da eleştirilen özelliğin "bakım" olduğu belirlenmiştir. Özellikle 
park içerisinde çöp kutusu vb. donatı elemanları sayısının az olmasının park içerisinde yoğunluğa bağlı olarak kirliliğe neden olduğu tespit edilmiştir. Ayrıca yapılan arazi gözlemleri sonucunda park içerisinde bulunan ağaç, ağaççık ve çalılıların budama, temizleme vb. işlemlerinin yapılmadığı, bunun sonucunda da kullanıcıların alan içerisindeki kullanımlara yönelik estetik kaygılarının arttığı söylenebilir.

"Doğal, çevreye uyumlu, iklime uygun" kriterler kullanıcı görüşleri açısından değerlendirilmiştir. Park içerisinde alanda ağaç, çalı vb. bitkiler bulunmaktadır. Yapılan arazi gözlemleri sonucunda park içerisinde bulunan bitkilerin bölge iklim koşullarına uygun oldukları tespit edilmiştir. Yapılan anket çalışması sonucunda kullanıcılar estetik kriterlerden doğal, çevreyle uyumlu ve iklime uygun kriterlerine ortalama 4,0 puana yakın bir değer verdikleri tespit edilmiştir. Bunun sonucunda park içerisinde bulunan bitkilerin estetik ve fonksiyonel kriterler doğrultusunda kullanıcılar tarafından beğenildiği söylenilir. Kullanımların estetik ve fonksiyonel olarak uygun görülmesi alanda düşünülen kullanımların çevreye uyumuna bağlıdır. Bu kullanıcıların park içerisindeki estetik değerlere bakışını değiştirebilmektedir. Bu yüzden yapay yüzeyler (yapı, amfi, merdiven vb.) park içerisinde fazla yoğunluğa neden olmamalı ve alan içerisinde bulunan doğal vejetasyona ait türleri içeren bitkilendirilmiş alanlar ya da geçirimli yüzeyler artırılmalıdır.

Peyzaj tasarımında "bitkisel tasarım" konusu oldukça önemli bir yer tutmaktadır. Bu yüzden alan içerisinde bulunan bitkisel öğelerin (ağaç, çalı, ağaççı vb.) sadece estetik kaygılarla değil, fonksiyonel kriterleri ile beraber düşünülmesi gerekmektedir. Bitkisel tasarımın, alan içerisinde bulunan kötü görüntülerin kapatılması, dokusu ve çiçekleriyle dinlendirici ve ferahlatıcı olması gerekmektedir. Yapılan arazi gözlemleri sonucunda çalışma alanında yapılan bitkisel tasarımın bu yönde fazla düşünülmediği tespit edilmiştir. Bitkisel tasarımında önemli olan bir diğer husus ise seçilen bitkilerin alanın iklim koşullarına uygun olmasıdır. Çalışma alanında kullanılan bitkilerin bölgenin iklimine uygun oldukları tespit edilmiştir. Yapılan arazi gözlemleri sonucunda park içerisinde bulunan kullanıcıların Antalya İl'inin yazları çok sıcak olduğundan dolayı açık alanlar yerine bitkilendirimiş alanları tercih ettikleri tespit edilmiştir. Çalışma alanının yazları sıcak olduğu düşünüldüğünde daha fazla sayıda gölge yapan ağacın kullanılmasının parkın tercih edilebilirliğini artıracağı söylenebilir.

Kentsel açık ve yeşil alanlar içerisinde bulunan parklar herkes için kullanılabilir ve ulaşılabilir olmalıdır. Bu yüzden parklar içerisinde bulunan kullanımların fonksiyonlarının herkes için uygun olması gerekmektedir. Kent parklarından tüm insanların (engelliler, yaşlılar, çocuklar) yararlandığı düşünülerek estetik ve fonksiyonel kriterler doğrultusunda parkların planlanmasının ve tasarlanmasının yararlı olacağı söylenebilir. Özellikle yaşlı ve engelli bireyler için alan içerisinde bulunan kullanımlar standartlara uygun bir şekilde tasarlanmalı ve uygulanmalıdır. Park giriş ölçüleri engelli bireylerin geçebileceği genişlikte olmalıdır. Kullanımlara giden yollar uygun eğimde ve genişlikte yapılmalıdır.

Yapılmış olan peyzaj tasarımının başarıya ulaşmasının temel amacı insanlar tarafından tercih edilmesidir. Bu yüzden herhangi bir alanda tasarım yapılmadan önce, kullanıcılar araştırılmalı, istek ve talepleri alınmalı, tasarım bu yönde geliştirilmelidir. Yapılan anket çalışması sonucunda her bir yaş grubu ve eğitim düzeyine göre tercihlerin değiştiği tespit edilmiştir (bknz. Tablo 7). Bu yüzden her bir kullanıc özelliğine göre park içerisinde bulunan kullanımlar düşünülmeli ve tasarlanmalıdır. Çalışma kapsamında incelenen parkın tercih edilebilirliğinin artırılması amacıyla çeşitli faaliyet ve aktiviteler geliştirilebilir. Örneğin: mevcut spor alanlarına ek keşif ve macera alanları eklenmelidir. Park içerisinde çocuk eğitim parkurları, sergi, satranç, gösteri, sanatsal ve kültürel etkinlik alanları için küçük bir amfi eklenmelidir. Parkın yakının deniz bulunduğu için su yüzeyinde gezintinin yapılabileceği su bisikleti, kano ve kayık ile gezinti alanları oluşturulmalıdır. Akşam/gece faaliyetleri artırılmalı, buna yönelik eğlenceler düzenlenmelidir. Yaşlı olan insanlar için ise seyir terasları oluşturulmalı, onlara özel vakit geçirebilecekleri (yürüyüş, okuma vb.) alanların sayıları artırılmalıdır.

Sonuç olarak, çalışma kapsamında incelenen park içerisinde bulunan kullanımların kullanıcılar açısından tercih edildiği tespit edilmiştir. Çünkü kullanıcıların her bir kriter için vermiş oldukları puanların ortalamaları 3,50 - 4,00 arasında değişmektedir. Bu yüzden çalışma kapsamında incelenen parkın estetik ve fonksiyonel kriterler doğrultusunda kullanıcılar tarafından beğenildiği söylenebilir. Parkın büyüklüğü, park içerisinde bulunan kullanımların fazla olması, konumunun iyi planlanmış olması parkın iyi yönleri arasından sayılabilir. Kullanıcılarının parka çoğunlukla şahsi araçla gelmeyi tercih ettikleri görülürken, arazi üzerinde yapılan görüşmeler sonucunda ulaşımın çeşitli ulaşım araçlarıyla kolaylıkla yapıldığı ifade edilmiştir. Kullanıcılar parkın yakın olduğunu ve ulaşımın kolay olduğunu belirtmişlerdir. Buna göre alana farklı ilçelerden toplu taşıma araçlarıyla ulaşmak isteyen kullanıcıların ulaşım 
konusunda sorun yaşamadıkları için kent parkını tercih etmek istedikleri sonucunu ortaya çıkarmaktadır.

Ancak parkın içerisinde bulunan kullanımların tercih edilebilirliğini artıran, iyi bir tasarım sürecinin yapılması gerekmektedir. Ayrıca sadece estetik kaygılar düşünülmemeli, alan içerisinde bulunan kullanımların fonksiyonel kriterleri de düşünülmelidir. Bunların yanında tasarım sürecine kullanıcılar mutlaka dâhil edilmeli ve onların istek ve görüşleri doğrultusunda planlama ve tasarım yapılmalıdır. Kullanıcılar tarafından parkların tercih edilmesinde manzara güzelliği önemli bir parametredir. Parkların planlamasında, tasarım aşamasında ve yönetimi tarafından dikkate alınması gereken bir parametredir. Öyle ki parkların manzara güzelliğinin yüksek olması cazibe merkezleri haline gelecektir. Bu yüzden parklardaki manzara noktaları artırılmalıdır. Ülkemizde özellikle açık ve yeşil alanlarda yapılan peyzaj tasarımlarının benzer olduğu, alana ya da mekâna yönelik tasarımların yapılmadığı, kullanıcıların istek ve görüşleri dikkate alınmadan uygulama sürecinin başladığı belirlenmiştir.

\section{KAYNAKLAR}

Akyol, E., 2006. Kent Mobilyaları Tasarım Ve Kullanım Süreci. İstanbul Teknik Üniversitesi, Fen Bilimleri Enstitüsü, Peyzaj Mimarlığı Anabilim Dalı, Yüksek Lisans Tezi, 125s., İstanbul

Bayazıt, E., (2018). Kentsel Donatı Elemanlarının Kent Kimliği Ve Estetik Değerler Yönünden İncelenmesi: Trabzon Ve Hükümet Caddeleri Örneği, Kahramanmaraş. Kahramanmaraş Sütçü İmam Üniversitesi, Fen Bilimleri Enstitüsü, Peyzaj Mimarlığı Anabilim Dalı, Yüksek Lisans Tezi, 173 s., Kahramanmaraş

Graham, C.A., (1995). Context and connection: evaluating succes in urban parks. The Thesis of Master of Architecture, Urban and Regional Plannıng. Faculty of the Graduate School of The University Of Texas At Arlington, USA.

Ghorab, P., (2015). Kent Mobilyalarının Temel Tasarım İlkelerine Göre Değerlendirilmesi. İstanbul Aydın Üniversitesi, Fen Bilimler Enstitüsü, Mimarlık Anabilim Dalı, Mimarlık Programı, Yüksek Lisans Tezi, 90s., İstanbul.

Güreşçioğlu, S., Demir, Z., (2019). Düzce Melensu Parkının Kullanıcı Memnuniyeti Açısından Değerlendirilmesi. Safran Kültür ve Turizm Araştırmaları Dergisi, 2(1), 38-51. Karabük.

Karakaya, N., (2019). Yaşam Kalitesinin Arttırılmasında Kent Parklarının Önemi: Eskişehir İli Örneğinde İncelenmesi. Çanakkale Onsekiz Mart Üniversitesi, Fen Bilimleri Enstitüsü, Peyzaj Mimarlığı Anabilim Dalı, Yüksek Lisans Tezi, 148 s., Çanakkale.

Kayha, C., (2018). Sakarya Kent Park Ve Sakarya Park Örneklerinde Kullanıcı Memnuniyeti Ve Kalite Karşılaştırması. Düzce Üniversitesi, Fen Bilimleri Enstitüsü, Peyzaj Mimarlığı Anabilim Dalı, Yüksek Lisans Tezi, 143 s., Düzce

Kurtaslan, B. Ö., (2017). Başarılı Kent Parkı Planlama ve Yönetimi Yaklaşımının Teardrop Park (New York) Örneğinde Araştırılması. OPUS Toplum Araştırmaları Dergisi. Volume:7, Cilt:7, Kayseri. DOI: 10.26466/opus.354010

Nasuh, D., (1993). Kent Parklarının Nitelikleri ve Ankara Örneğinde İrdelenmesi. Ankara Üniversitesi, Fen Bilimleri Enstitüsü, Peyzaj Mimarlığı Anabilim Dalı, Yüksek Lisans Tezi, 154 Sayfa. Ankara

Ocak, R. Ö., Perçin, H. (2014). Bazı Kent Parklarının Tasarım Anlayışlarının İncelenmesi. Selçuk Tarım Bilimleri Dergisi, 1(1), 12-20, Konya.

Oğuz, D,. (1998). Kent Parkı Kavramı Yönünden Ankara Kent Parklarının Kullanım Olgusu Üzerine Bir Araştırma. Ankara Üniversitesi, Fen Bilimleri Enstitüsü, Peyzaj Mimarlığı Anabilim Dalı, Doktora Tezi, 290 sayfa. Ankara.

Özkır, A. (2007). Kent Parkları Yönetim Modelinin Geliştirilmesi. Ankara Üniversitesi, Fen Bilimleri Enstitüsü, Peyzaj Mimarlığı Anabilim Dalı, Doktora Tezi. 187 Sayfa. Ankara. 
Sonkur, B., Durak, M., Tazebay, İ., (2017). Kent Parkı Kullanımı Ve Öznel İyi Oluş İlişkisi: Ankara Kenti Örneği. Uluslararası Mimarlık ve Tasarım Dergisi. Sayı:10, İstanbul. Doi: 10.17365/TMD.2017.1.006.x

Şatıroğlu, E., Bayramoğlu, E., Pouya, S., (2017). Kent Parklarının Estetik İşlev Açısından Değerlendirilmesi..2. Uluslararası Mühendislik Mimarlık Ve Tasarım Kongresi Kitabı s:539 - 550. 12 - 13 Mayıs 2017 Kocaeli.

Yazıcıoğlu, Y., Erdoğan, S., (2004). SPSS Uygulamalı Bilimsel Araştırma Yöntemleri. ss:448, ISBN: 9789758326983, Detay Yayıncılık, Ankara

Yıldırım, C., (2011). Antalya Kenti İçindeki Parklarda Yer Alan Donatı Elemanlarının Estetik Ve Fonksiyon Açısından Değerlendirilmesi. Akdeniz Üniversitesi, Fen Bilimleri Enstitüsü, Peyzaj Mimarlığı Anabilim Dalı, Yüksek Lisans Tezi, , 132 s, Antalya

\section{EXTENDED ABSTRACT}

Introduction: Public spaces in the cities are important areas for the collective memory and urban identity. They form the identity of the city and reflect the collective memory of the society. Urban parks are one of the significant public spaces and they are cultural heritage of the cities. Park designs bridge from past to future, so they introduce the evolutionary process of the past and create visions for the future. The representative exemplars of the city park designs form the iconic image of the cities. These democratic public spaces gather urban inhabitants and visitors and contribute to the collective memory. In addition, the importance of their roles in our future is increasing day by day. City parks as public spaces gather nature and urban dwellers and form breathing centers in the city. They provide natural habitats for urban fauna and space for recreational activities, reduce urban heat island effect and clean the air, can help to manage storm water with trees and grasses. Hence, their environmental benefits and social meanings concentrate both ecology and culture (Karaali, 2018:1-2). Urban parks are very important for the city image. Therefore, the design of parks should be considered as multifaceted. Parks should not only be considered as green areas, but parks should be designed in accordance with aesthetic and functional criteria. Only this way, urban parks can meet all the needs of users.

In this study, areas in the Prof. Dr. Erdal İnönü City Park were evaluated in terms of user opinions according to aesthetic and functional criteria. In this study, it has been determined how the urban park responds to the aesthetic and functional needs. It is thought that the results of the research will give a new vision to the parks planned to be made in Antalya Province. The basic question of the study is as follows: 1 . Are the aesthetic and functional principles of the landscape design process of the parks important? 2. Is the landscape design process started by taking user opinions? The answer to these questions has been examined within the scope of this study.

The areas in the park have been determined and maps for each area were created. A survey study was conducted in order to get the opinions of the users about the park. Data was evaluated by using descriptive statistics. As a result of the data obtained from the survey study, the map was created according to each criteria. The study consists of five stages. In the first stage, the studies on the subject of study were examined. The second stage is data collection and field studies. The third stage is to prepare the survey, to determine the sample and to make surveys to the users. The fourth stage is that survey studies were analyzed. In the final stage, suggestions for the landscape design process of the parks are given.

Area of park is 25 acres. There are 11 usages areas in the park. These are: Children's Playground, Open green areas, Swimming pool, Aqua Park, Cafe, Restaurant, Observation terrace, Wedding hall, Association building, Beach and Sun terrace, Park Square. Most participants in the survey were men and old. Their income is high. Most of the participants live near the park. Some of visitors comes from other districts to the park. The most of the users come to the park for rest. "Attractive criterion" has the lowest score 3,00 and highest score 4,62. "Beautiful criterion" has the lowest score 3,07 and highest score 4,54. "Compatible with the environment criterion" has the lowest score 3,35 and highest score 4,68. "Well-groomed criterion" has the lowest score 3,36 and highest score 4,40. "Natural criterion" has the lowest score 3,33 and highest score 4,44. "Magnificent criterion" has the 
lowest score 3,33 and highest score 4,61. "Moving criterion" has the lowest score 3,40 and highest score 4,36. "Refresher and amazing criterions" have the lowest score 3,29 and highest score 4,52. "Large criterion" has the lowest score 3,38 and highest score 4,38. "Guidance criterion" has the lowest score 3,22 and highest score 4,48. "Relaxing criterion" has the lowest score 3,46 and highest score 4,50. "Suitable for climate criterion" has the lowest score 3,02 and highest score 4,23. "Suitable for disabled people criterion" has the lowest score 3,01 and highest score 4,00. "Suitable for old people criterion" has the lowest score 3,01 and highest score 4,20. These criteria are examined in terms of aesthetic and functional principles (min:11 - max:55). "Aesthetic criterion" has the lowest score 36,88 and highest score 48,55. "Functional criterion" has the lowest score 22,19 and highest score 30,03 . There is determined that square and entrance of the park are the most favorite areas in the park. Garden, cafe and surround of ornamental pool which are found in the middle of the park, are less favorite areas in the park. Building and playground which are found in the east and southwest of the park, are not favorite by users. Preferences have shown significant difference according to variables such as age, occupation and income. But preferences have not shown significant difference according to variables such as education and sex. The main purpose of the success of the landscape design is to be liked by users. Therefore, before landscaping design is done in any area, users should be investigated, requests and demands should be taken and landscape design should be developed in this direction. 


\section{Ek-1}

\section{A) Sosyo - Ekonomik Durum}

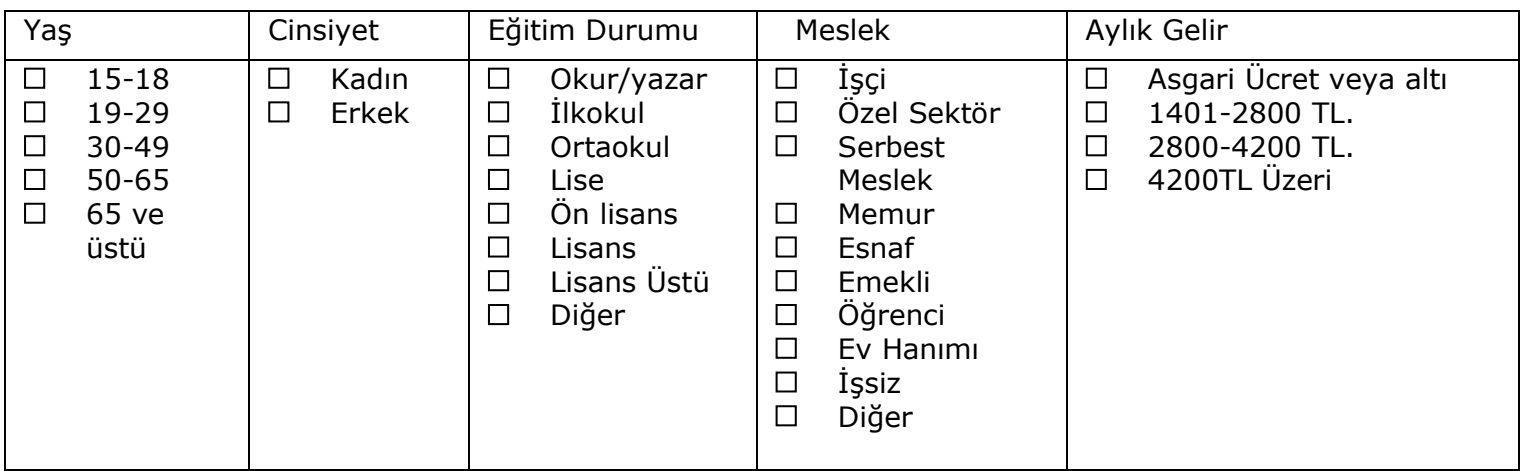

1. Hangi Mahallede ikamet ediyorsunuz?

2. Erdal İnönü Kent Parkı'nı hangi kullanım alanı için tercih ettiniz?

B) Prof. Dr. Erdal İnönü Kent Parkı'ndaki Kullanım Alanlarının Değerlendirmesi (Aşağıdaki tabloda belirtilen kriterler "Kent Parkı Giriși ve Çevresi, Park Meydanı ve Çevresi. Kır Kahvesi Çevresi, Aquapark ve Cevresi, Yüzme Havuzu ve Cevresi, Kafe Çevresi, Dernek Binası Çevresi, Çocuk Oyun Alanı, Plaj / İskele Kullanım Alanları" için ayrı ayrı ankette sorulmuş ve değerlendirilmiștir)

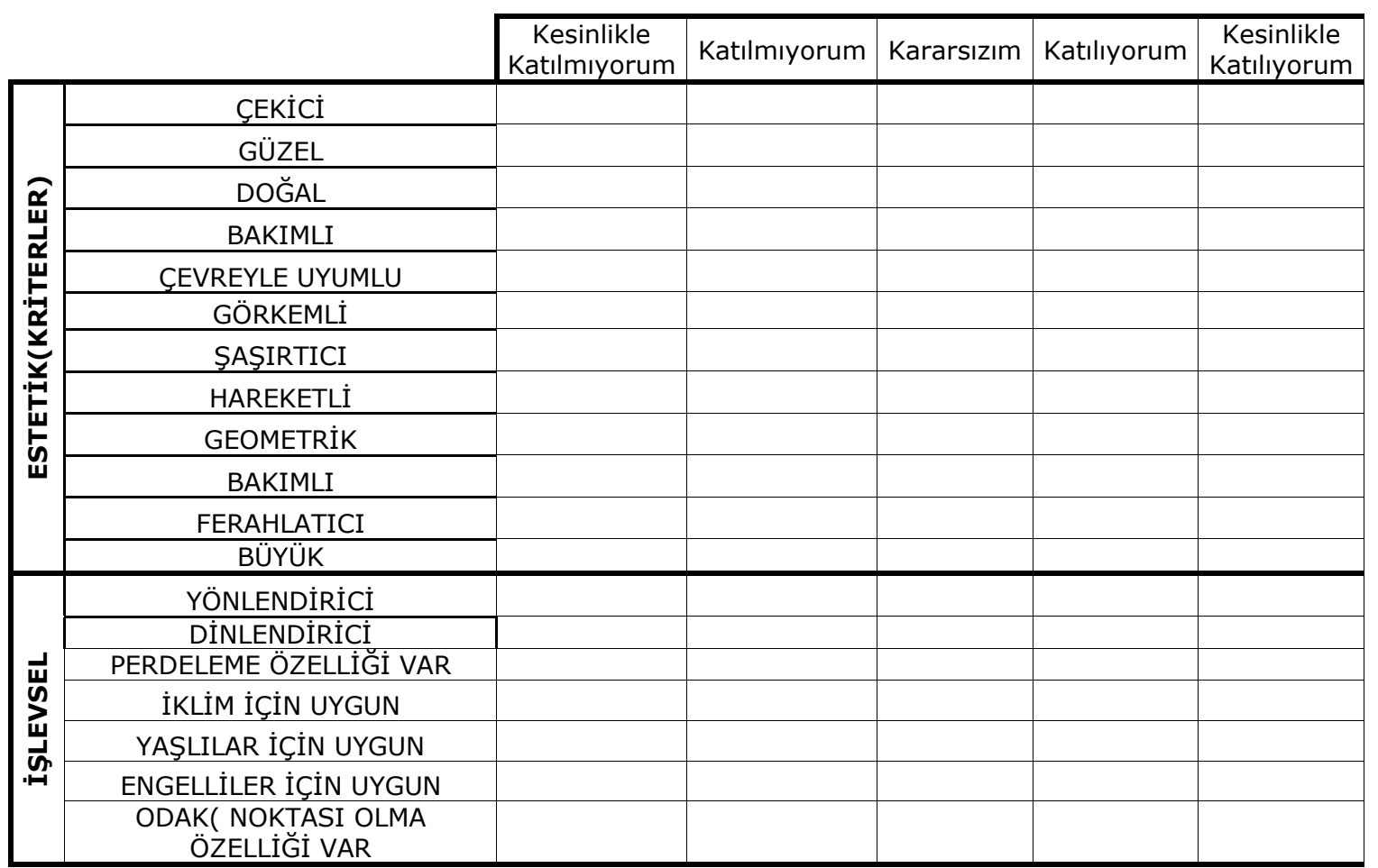

